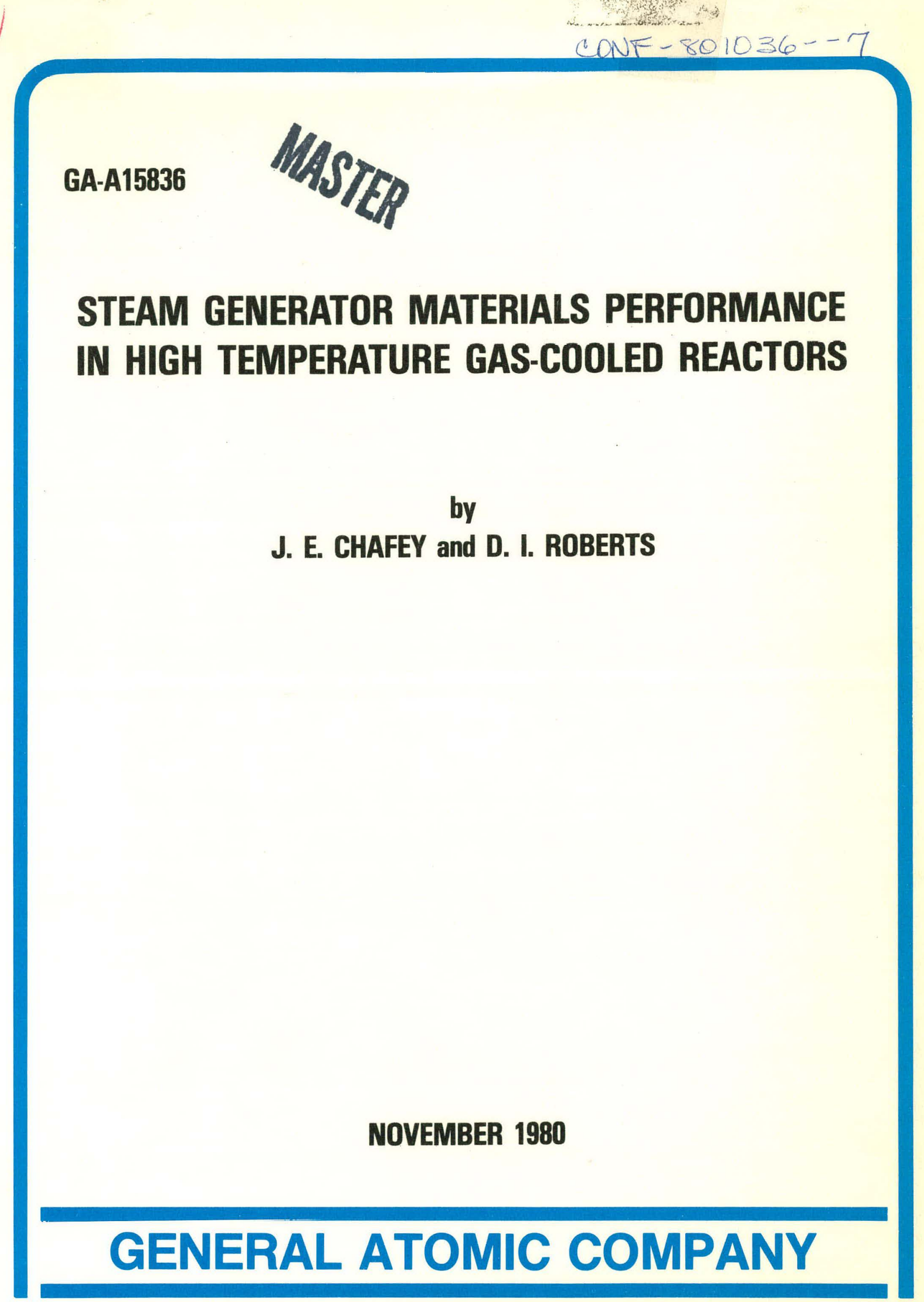




\section{DISCLAIMER}

This report was prepared as an account of work sponsored by an agency of the United States Government. Neither the United States Government nor any agency Thereof, nor any of their employees, makes any warranty, express or implied, or assumes any legal liability or responsibility for the accuracy, completeness, or usefulness of any information, apparatus, product, or process disclosed, or represents that its use would not infringe privately owned rights. Reference herein to any specific commercial product, process, or service by trade name, trademark, manufacturer, or otherwise does not necessarily constitute or imply its endorsement, recommendation, or favoring by the United States Government or any agency thereof. The views and opinions of authors expressed herein do not necessarily state or reflect those of the United States Government or any agency thereof. 


\section{DISCLAIMER}

Portions of this document may be illegible in electronic image products. Images are produced from the best available original document. 
This report was prepared as an account of work sponsored by an agency of the United States Government. Neither the United States Government nor any agency thereof, nor any of their employees, makes any warranty, express or implied, or assumes any legal liability or responsibility for the accuracy, completeness, or usefulness of any information, apparatus, product, or process disclosed, or represents that its use would not infringe privately owned rights. Reference herein to any specific commercial product, process, or service by trade name, trademark, manufacturer, or otherwise, does not necessarily constitute or imply its endorsement, recommendation, or favoring by the United States Government or any agency thereof. The views and opinions of authors expressed herein do not necessarily state or reflect those of the United States Government or any agency thereof. 
GA-A15836

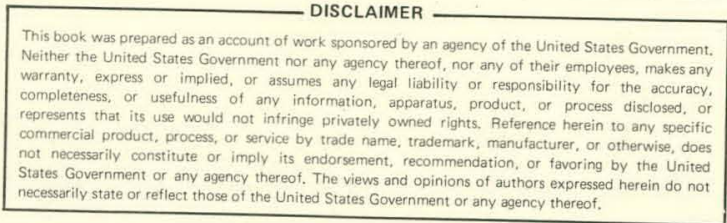

\title{
STEAM GENERATOR MATERIALS PERFORMANCE IN HIGH TEMPERATURE GAS-COOLED REACTORS
}

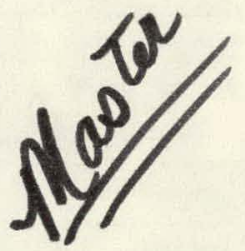

\author{
by \\ J. E. CHAFEY and D. I. ROBERTS
}

This is a preprint of a paper presented at the ANS International Conference on Materials Performance in Nuclear Steam Generators, October 6-9, 1980, St. Petersburg, Florida and to be published in Nuclear Technology.

Work supported in part by Department of Energy Contract DE-AT03-76ET35300

GENERAL ATOMIC PROJECT 7400 NOVEMBER 1980

\section{GENERAL ATOMIC COMPANY}




\section{THIS PAGE}

WAS INTENTIONALLY

LEFT BLANK 
ABSTRACT

This paper reviews the materials technology aspects of steam generators for high-temperature gas-cooled reactors (HTGRs). This advanced reactor system features a graphite-moderated, uranium-thorium, al1-ceramic core and utilizes high-pressure helium as the primary coolant. The steam generators in these systems are exposed to gas-side temperatures approaching $760^{\circ} \mathrm{C}$ $\left(1400^{\circ} \mathrm{F}\right)$ and produce superheated steam at $538^{\circ} \mathrm{C}\left(1000^{\circ} \mathrm{F}\right)$ and $16.5 \mathrm{MPa}(2400$ psi). Thus, the design and development of steam generators for these systems require consideration of time-dependent materials behavior, corrosion, fretting, wear, and related phenomena of concern in all steam generators.

The prototype Peach Bottom I 40-MW(e) HTGR was operated by the Philadelphia Electric Company for a total of 1349 equivalent full-power days (EFPD) over 7 years. Upon planned decommissioning of this plant, the forced-recirculation U-tube steam generators and other components were subjected to destructive metallurgical examination. This examination, the results of which are described in this paper, showed the steam generators to be in very satisfactory condition.

The 330-MW(e) Fort St. Vrain HTGR, owned and operated by Public Service Company of Colorado and now in the final stages of startup, has achieved $70 \%$ power and generated more than $1.5 \times 10^{6}$ MWh of electricity. The steam generators in this reactor are once-through units of helical configuration, and 
their design and development required considering a number of new materials factors including creep-fatigue. Also, since these are once-through units, water chemistry control needed special consideration.

.

Current designs of larger HTGRs also feature steam generators of helical once-through design. Materials issues that are important in these designs include detailed consideration of time-dependent behavior of both base metals and welds, as required by current American Society of Mechanical Engineers (ASME) Code rules, evaluation of bimetallic weld behavior, evaluation of the properties of large forgings, etc. 


\section{INTRODUCTION}

Figure 1 illustrates the principal features of high-temperature gas-cooled reactors (HTGRs). The reactor core consists of graphite blocks, which act as both moderator and structure and contain the fuel that generates fission heat. The fuel used may be either the carbides or oxides of uranium and thorium. The system is cooled by high-pressure helium which, in a typical steam-cycle HTGR, enters the core at temperatures of $\sim 320^{\circ} \mathrm{C}$ $\left(\sim 650^{\circ} \mathrm{F}\right)$ and is heated to temperatures of $\sim 760^{\circ} \mathrm{C}\left(1400^{\circ} \mathrm{F}\right)$ by the core. The: helium is then circulated to heat exchangers, where the heat is transferred. and can be converted into energy for useful work. The cool helium is then recirculated back to the core; and the circuit continues. Because of the relatively high helium temperatures, the heat exchangers can be steam generators capable of generating high-pressure, high-temperature steam compatible with modern turbomachinery. Indeed, the all-ceramic reactor core gives the system the potential to go to very high core outlet temperatures [approaching $\left.1000^{\circ} \mathrm{C}\left(1832^{\circ} \mathrm{F}\right)\right]$, and currently, significant effort is being devoted to developing the reactor for high-temperature process heat applications. However, keeping within the context of this conference, this paper will focus on the steam generating (electricity producing) version of this reactor system.

HTGRs have been under development for more than 20 years. During that time, a number of units have been developed, and several are still under construction or development, as shown in Table $I$. Of the reactor systems 
shown in Table I, only four feature steam generators that produce modern high-pressure, high-temperature steam (see Table II). These are the Peach Bottom, Fort St. Vrain, Thorium Hoch Temperatur Reaktor (THTR), and 1arge HTGR systems. The Peach Bottom reactor was operated for seven years and has been shut down, decommissioned, and the steam generators examined. The Fort St. Vrain reactor has entered commercial operation, and substantial operating experience has been accumulated. The THTR in the Federal Republic of Germany is still under construction and, therefore, has yet to accumulate operating experience with its steam generators. Similarly, the large HTGRs are currently only in the design stage. Accordingly, this paper will focus on the units that feature these modern steam generators and will pay most attention to the Peach Bottom and Fort St. Vrain reactors; although, other systems will be referred to when appropriate.

\section{PEACH ВOTTOM 1}

The Peach Bottom Unit No. 1 prototype HTGR (Fig. 2) was operated by Philadelphia Electric Company for a total of 1349 equivalent full-power days (EFPD) over / years between January 1967 and October 1974, when it was shut down for planned decommissioning. Table III gives relevant operating statistics, and Table IV gives the principal features of the operating environment.

Figure 3 shows the general layout of the Peach Bottom primary coolant system. The two steam generators, which were housed in separate pressure vessels, were forced-recirculator boilers with pendant U-tube economizer, 
evaporator, and superheater sections (see Fig. 4). Figure 5 is a photograph of a tube bundle. The photograph shows the original $304 \mathrm{H}$ stainless steei superheater bundle. However, prior to reactor commissioning, the superheater section encountered stress corrosion cracking; as a result, the superheater section was retubed with Alloy $800 .^{\mathrm{a}}$ Table $\mathrm{V}$ indicates the final steam generator materials selection and generating environment. The Alloy 800 tubes served throughout the operating life without any failures. Two small leaks occurred due to fabrication defects at the tubesheet, but these were so minor that they remained tolerable throughout the operation.

After decommissioning, a destructive examination program was undertaken to determine the reactor condition. The Department of Energy (DOE) and the Electric Power Research Institute (EPRI) spónsored this program. This examination evaluated the condition of one sream generator.

The top head of the steam generator was removed to examine the steam side of the tubes and tube sheets. The side of the pressure shell was cut, as shown in Fig. 6, to give access to the helium side of the superheater, and economizer, and evaporator tubing. In general, the steam generator internals appeared in excellent condition (see Fig. 7). Figure 7 shows a view of the superheater section; apart from some carbonaceous deposit on the tubes and some evidence of minor fretting damage where the tubes pass through the support plates (Figs. 8, 9), tube bundle showed essentially no evidence of degradation. Similarly, the economizer section (Fig. 10) was in excellent condition. 
To further evaluate the condition of the steam generator construction materials, metallographic and mechanical test specimens were removed and subjected to detailed metallurgical evaluation. In general, this examination confirmed that all construction materials were in excellent condition. As Fig. 11 indicates, no evidence of significant interaction was given between the Alloy 800 superheater tubing and the external helium environ= ment, although these helium-exposed surfaces showed rarhnn deposite (bclieved to have resulted from minor oil ingress into the reactor during operation). The internal, steam-exposed surfaces of the superheater tubing were covered by thin, protective, entirely satisfactory oxide films. Examination of these oxide films showed that the apparent rate of oxide growth was entirely consistent with the observations made by others (1) (see Fig. 12).

Similarly, the economizer and evaporator tubing showed nn evidence of adverse interaction with the primary coolant environment, and they showed the presence of protective oxide films of the cxpccted thickness un the steam and water sides (see Figs. 13, 14).

Evaluation of the mechanical properties of the exposed material showed that, in general, extended service had had relatively little effect. In the case of the Alloy 800 superheatar tubing, however, sulstantlal agc-härdening was noted to have occurred because of service exposure, resulting in a considerable strengthening (see Figs. 15, 16) and some loss of ductility (see Fig. 17). However, despite this thermal aging effect, the residual ductility of the material remained at entirely satisfactory values. 
The overall conclusion from the post-decommissioning examination of the Peach Bottom reactor was that all construction materials, including those used in the steam generator, appeared to have performed entirely satisfactorily and, from a materials viewpoint, were capable of many additional years continued exposure.

a

3. FORT ST. VRAIN

The 330-MW(e) Fort St. Vrain HTGR (Fig. 18), now operating on the Public Service Company of Colorado grid, has features which differ significantly from the Peach Bottom unit. Figure 19 shows the flow diagram for this reactor.

As indicated, the reactor utilizes a prestressed concrete pressure vessel (PCRV) (Fig. 20). The PCRV concept was chosen for its important inherent safety advantages. However, because this vessel type was chosen, the steam generators needed to be as compact as possible. To achieve this in the Fort St. Vrain plant, the steam generators chosen were once-through units comprising helically wound tubing.

The reactor contains 12 heat exchanger modules. Figure 21 shows a simplified schematic and Fig. 22 a photograph of one such module. Table VI indicates the construction materials and relevant operating environment for these units. As shown, Alloy 800 is used in the hottest sections of the superheater and reheater. The intermediate temperature superheater is $2-1 / 4$ $\mathrm{Cr}-1 \mathrm{Mo}$, and the remainder of each module is low alloy steel. 
l'able VI shows that the pressure-containing metal temperatures in this reactor are significantly higher than they were in the Peach Bottom units. As a result, in the design of the Fort St. Vrain units, considerable attention was directed toward elevated temperature design considerations. These steam generators were built before American Society of Mechanical Engineers (ASME) Boiler and Pressure Vessel Code rules for elevated temperature construction had approached the level of complexity that now exists in Code Case N-47. Nevertheless, the design of the Fort St. Vrain units considered fatigue, long-term time-dependent properties, and to some extent, creep/ fatigue interaction. In addition, because these steam generators are subject to high cross-tube gas flows, special attention was directed toward flow-induced vibration and related fretting and wear damage. After much testing, wear protection was provided by protective sleeve and tubing devices. Figure 23 shows a typical sleeve and wedge combination, and Fig. 24 shows these devices in place in a reheater bundle.

This reactor started power generation in December 1976 and, as indicated in Table VII, has, to date, generated very substantial amounts of electricity. Table VIII shows the reactor operating environments. The steam generators have shown very satisfactory operation. One tube leak was experienced in November 1977. The exact location of the tubc lcak was difficult to discern; however, the leak was located in the Alloy 800 superheater bundle section. Indications at the time suggested that this was simply a random failure, and subsequent operation without evidence of further leakages tends to confirm this view. 


\section{FUTURE, LARGE HTGRs}

A number of designs have evolved in recent years for large steamgenerating HTGRs. Due to the very satisfactory prior experience, the steam generators in these units are expected to have materials and configurations generally similar to the Fort St. Vrain reactor. For instance, the units will be helically wound, once-through units with Alloy $800 \mathrm{H}$ and $2-1 / 4 \mathrm{Cr}-1$ Mo as the principal construction materials.

However, the design of these future steam generators will be governed by the increasingly complex and sophisticated design rules of Code Cases $\mathrm{N}-47, \mathrm{~N}-48$, etc. These requirements impose the need for very complex and complete finite element analyses including consideration and analysis of creep/fatigue interacton phenomena, creep, ratchetting, and other failure modes. Moreover, the effects of specific environments on properties must be considered, as must the effects of fabrication factors, such as welding and bending, on materials behavior. Such analyses will require that existing data bases for construction materials be considerably extended.

Also, economic factors will almost certainly dictate that future HTGR steam generators have larger modules than were used in Fort St. Vrain. This will necessitate evaluating the properties of very large forgings, developing wear protection systems appropriate for the new configurations, and related factors. 


\section{CONCLUSIONS}

Overal1, HTGR steam generator materials have performed very satisfactorily. In particular, only one random-failure tube leak has occurred on Fort St. Vrain. generators. None failed at Peach Bottom. Examination of the Peach Bottom reactor 7 years of service indicated no significant materials, degradation of any kind. All indicators show that the Peach Bottom units could have operated for a great many more years.

In general, material selection for future units appears well founded, and the additional work on materials that currently appears needed is related to meeting modern code rquirements and responding to economically induced configuration changes. 


\section{REFERENCE}

1. Pearl, W. L., et a1., "General Corrosion of Materials for Nuclear Superheat Applications," USAEC Report GEAP-4760, General Electric Company, March 1965. 
FOOTNOTE

The designation of Alloy 800 has undergone many changes in the years subsequent to the building of the Peach Bottom reactor. For example, in modern U.S. codes and specifications, "Alloy 800 " refers to a form of material heat treated at relatively low temperatures to produce a fairly. finegrained high-yield-strength product. "Alloy $800 \mathrm{H}, "$ on the other hand, refers to a version of the material which is heat treated at very high temperatures to produce a coarser-grained creep-resistant material. This material is also required to have a carbon content in the upper half of the range permitted for "Alloy 800." At the time of Peach Bottom construction, the importance of heat treatment to properties was recognized, while the significance of carbon content was not. Thus, for high-temperature service, under conditions where creep strength was important, a material designated either "Alloy 800, Grade 2" or "Alloy 800-solution annealed" was specified. This material required high-temperature heat treatment, but did not have carbon control or specific minimum grain size control. The latter material was that employed in Peach Bottom. 
FIGURES AND TABLES 
THIS PAGE

\section{WAS INTENTIONALLY \\ LEFT BLANK}




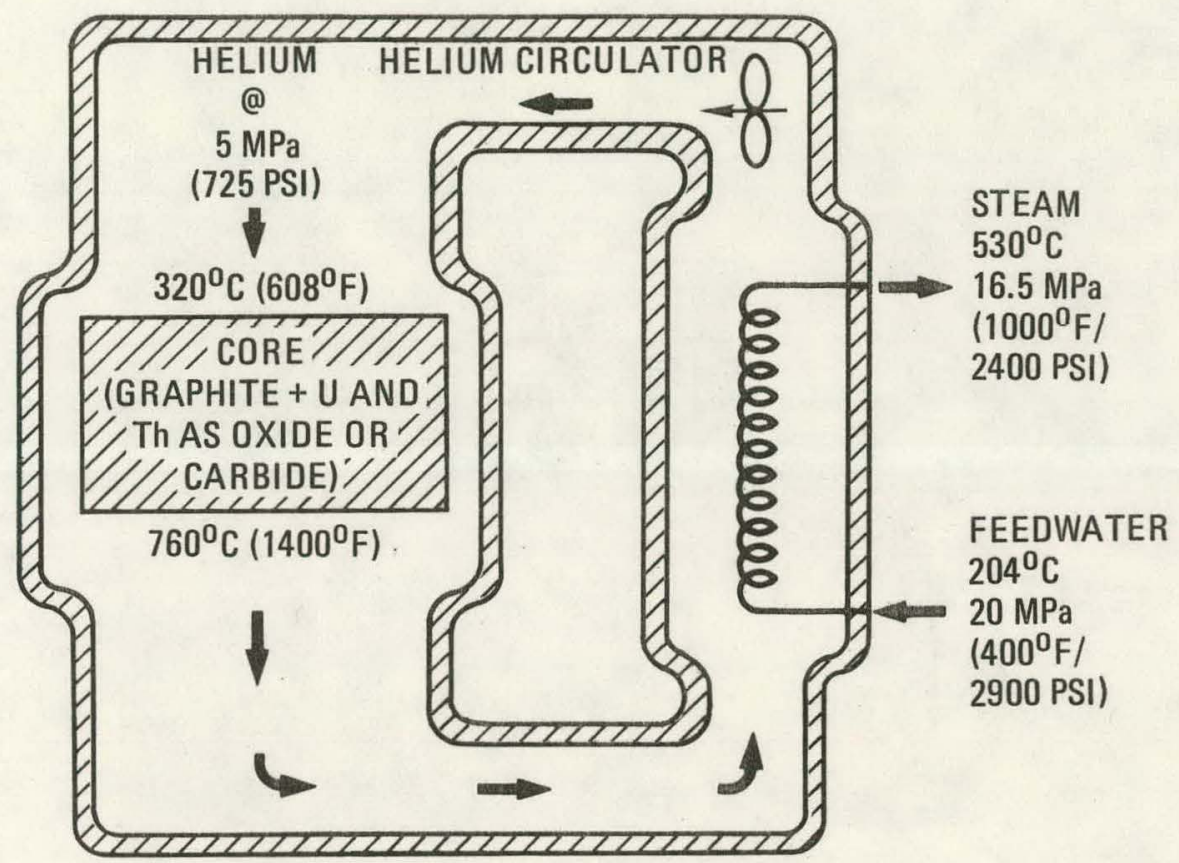

Fig. 1. Simplified schematic of steam generating HTGR 


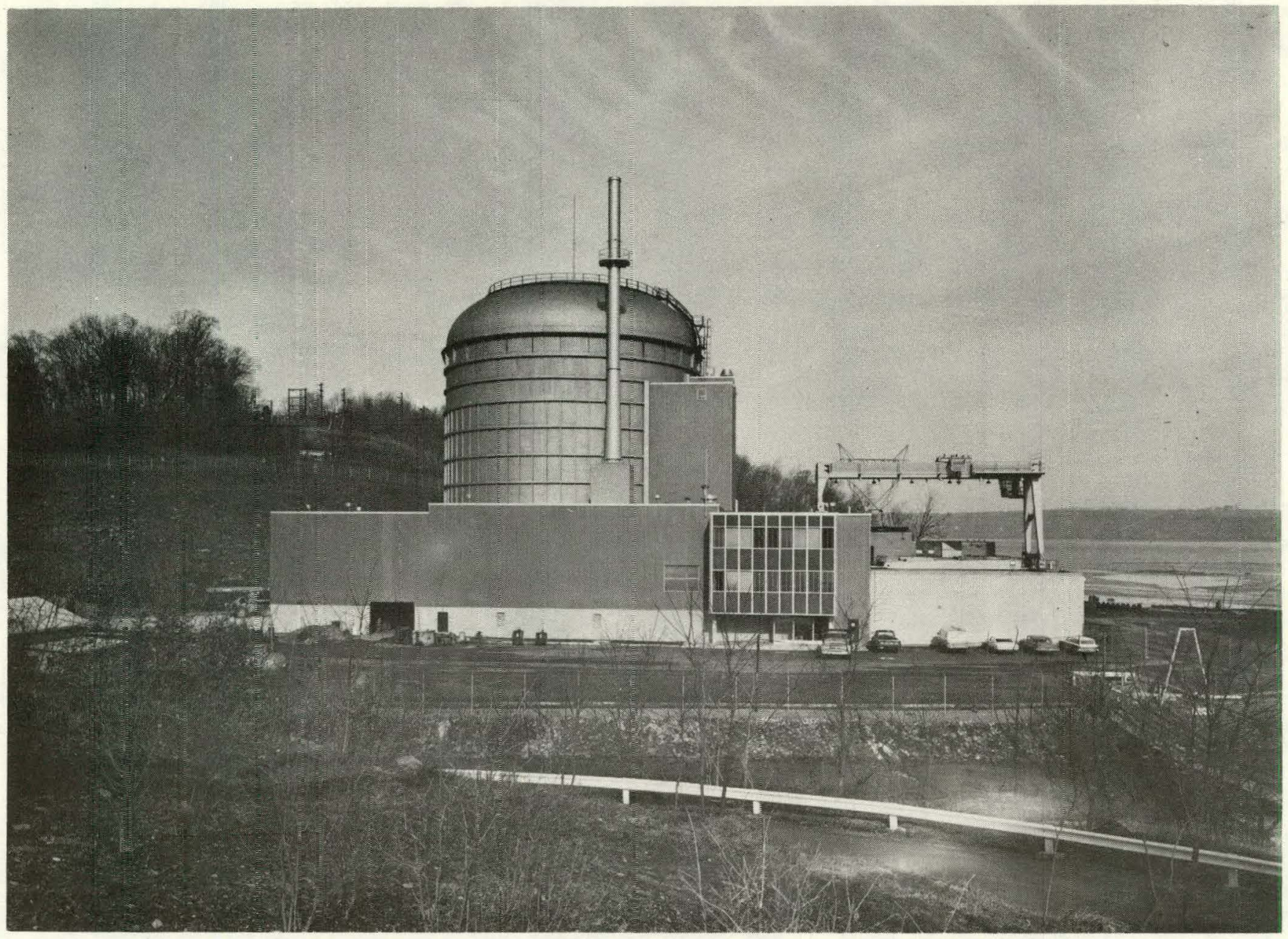

Fig. 2. Prototype 40-MW(e) HIGR at Peach Bottom, Pennsylvania 


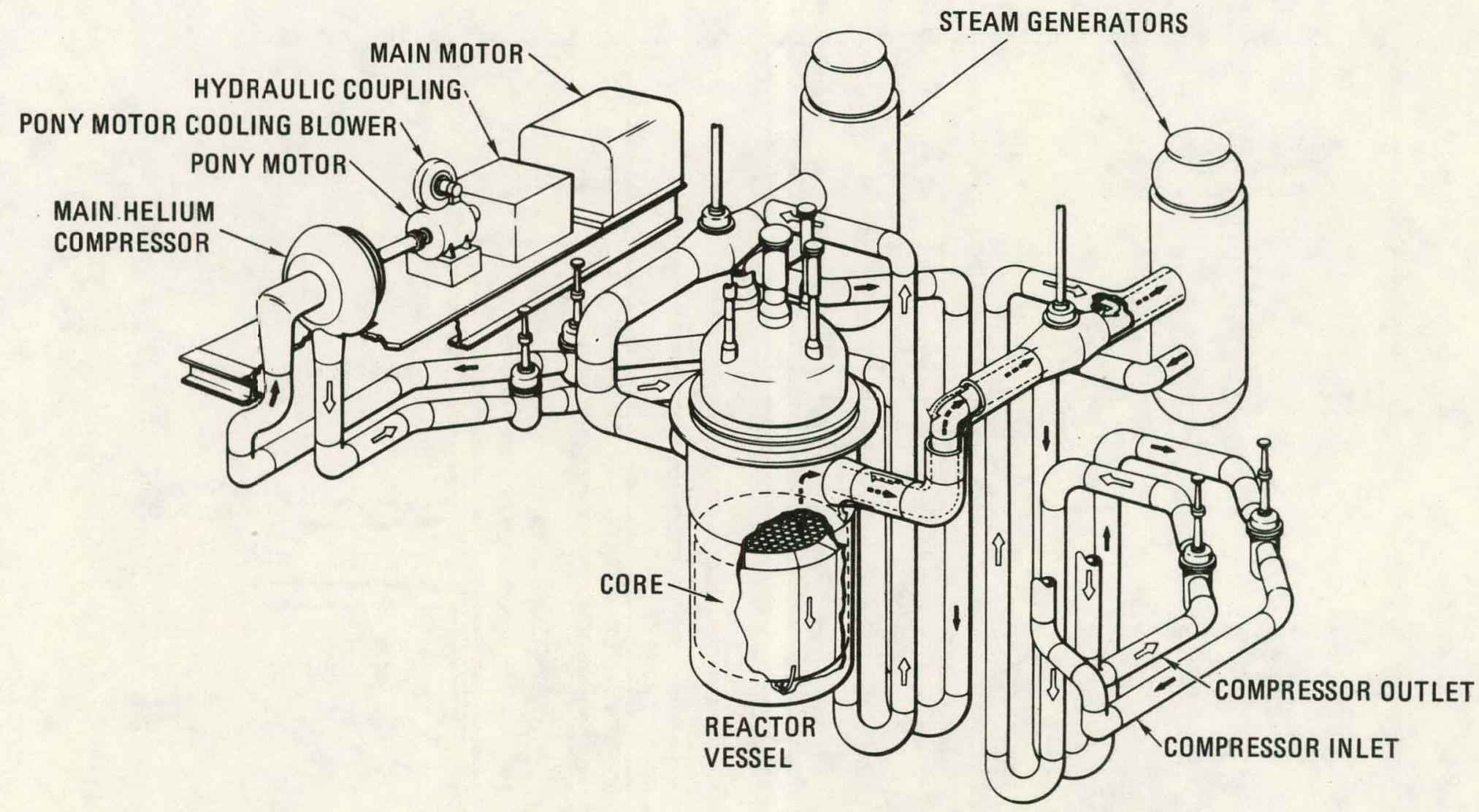

Fig. 3. Isometric view of primary coolant systems 


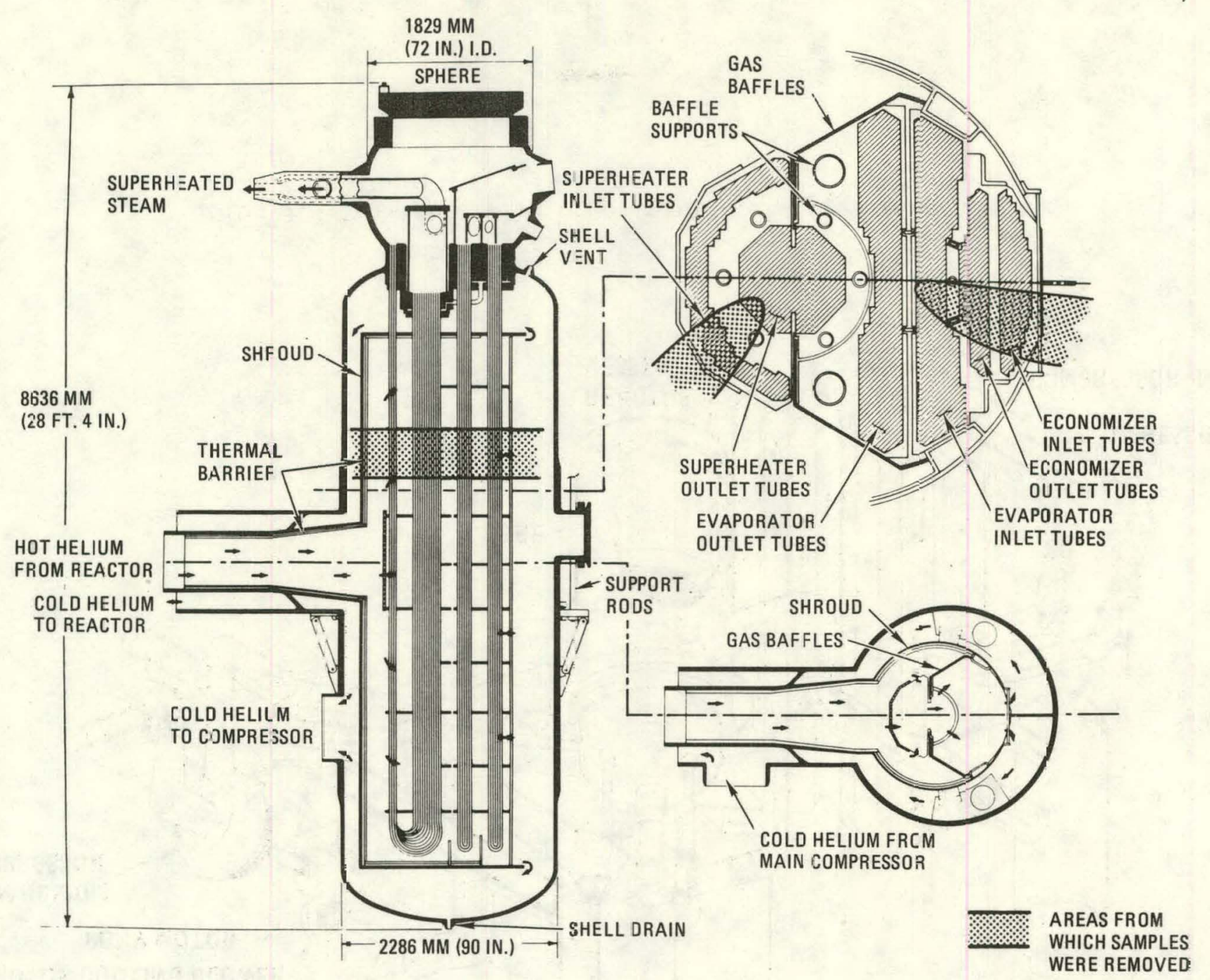

Fig. 4. Ste $\equiv m$ generator cros section showing sampling locations 


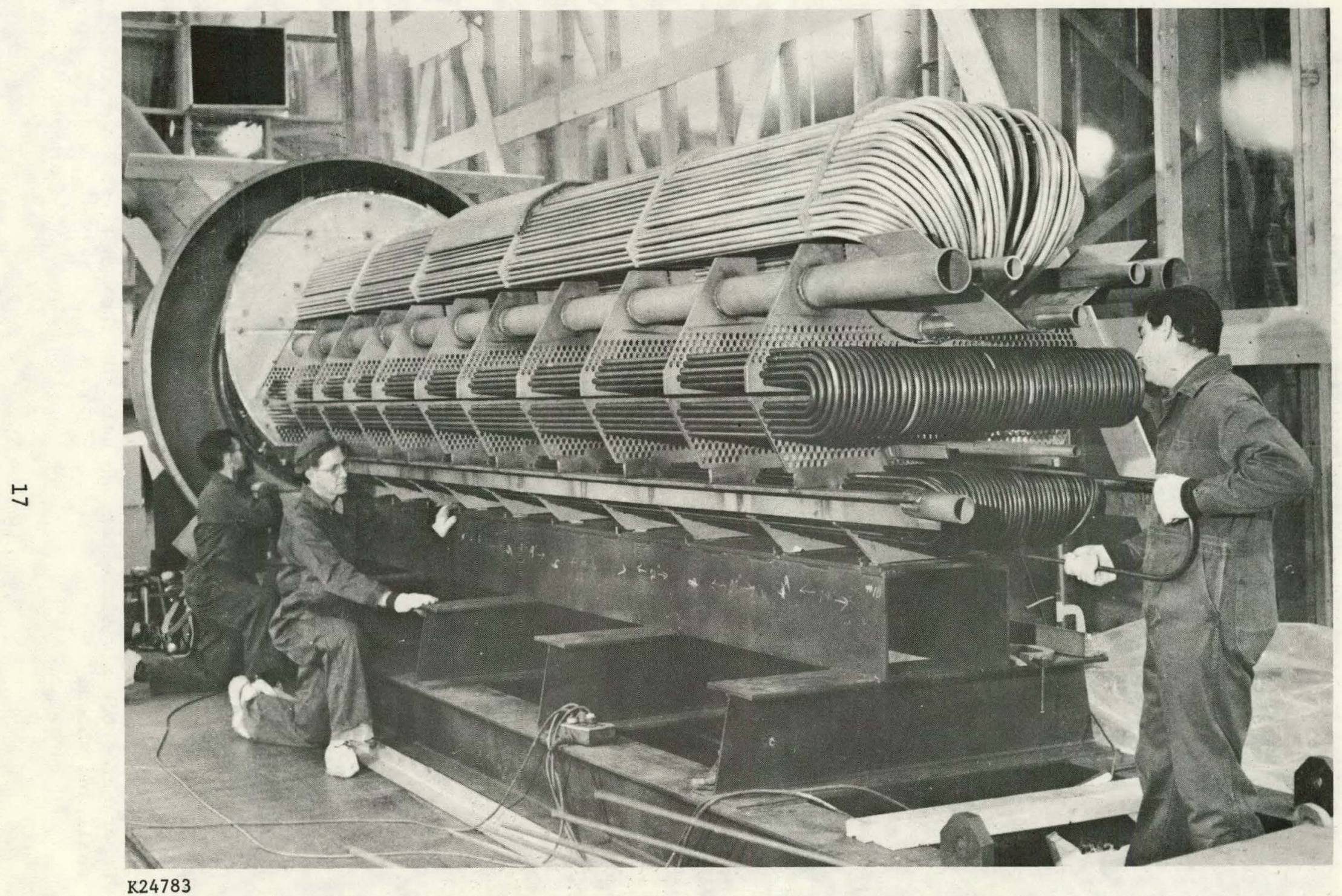

Fig. 5. Heat transfer section of one steam generator. Uppermost, light-colored tubes are the original $304 \mathrm{H}$ stainless steel superheater section, which was later retubed with Alloy 800 . Center region of tubes is the evaporator; lower tubes are the economizer. 


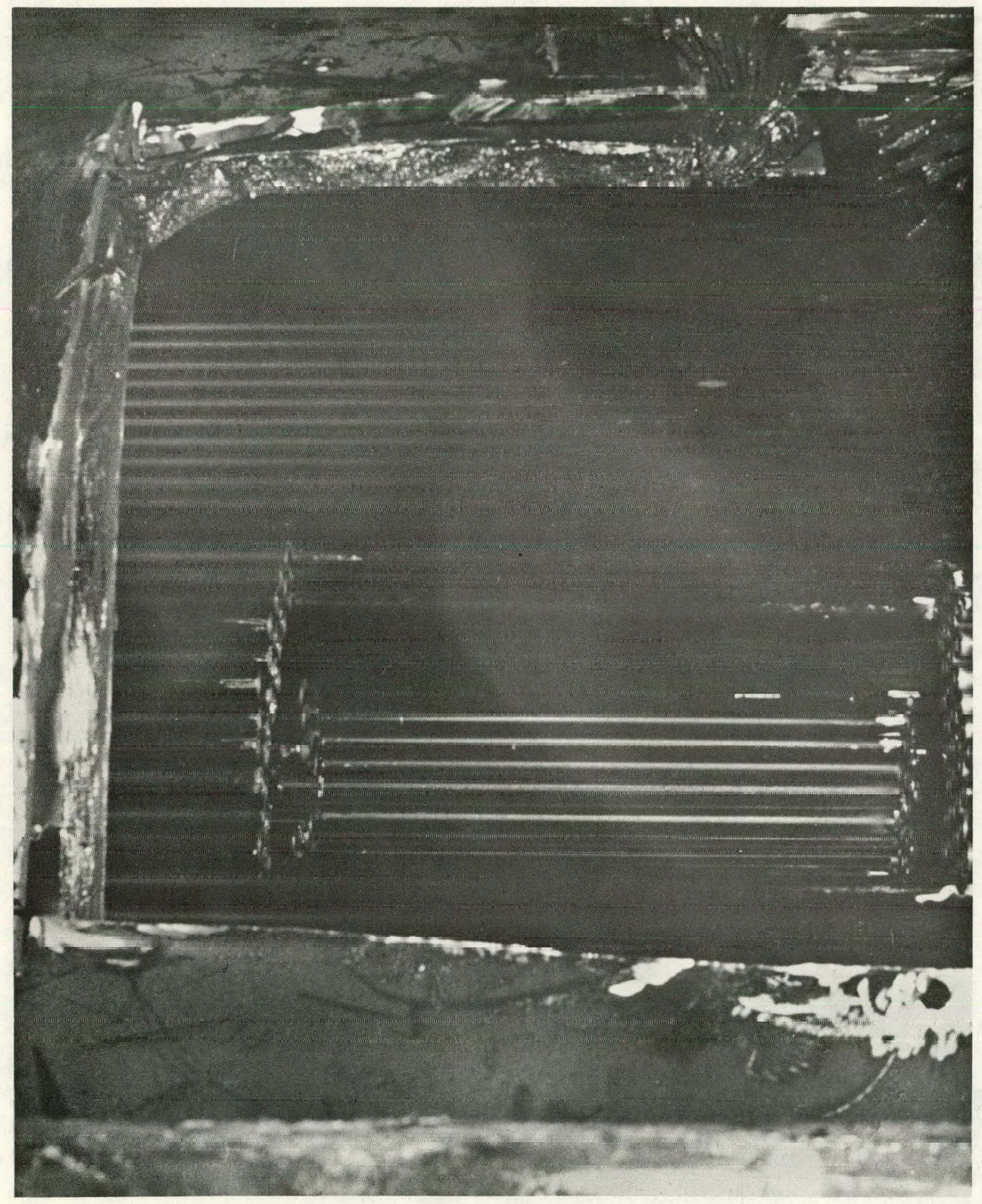

Fig. 6. Superheater tubes visible through hole cut through steam generator shell and shroud 


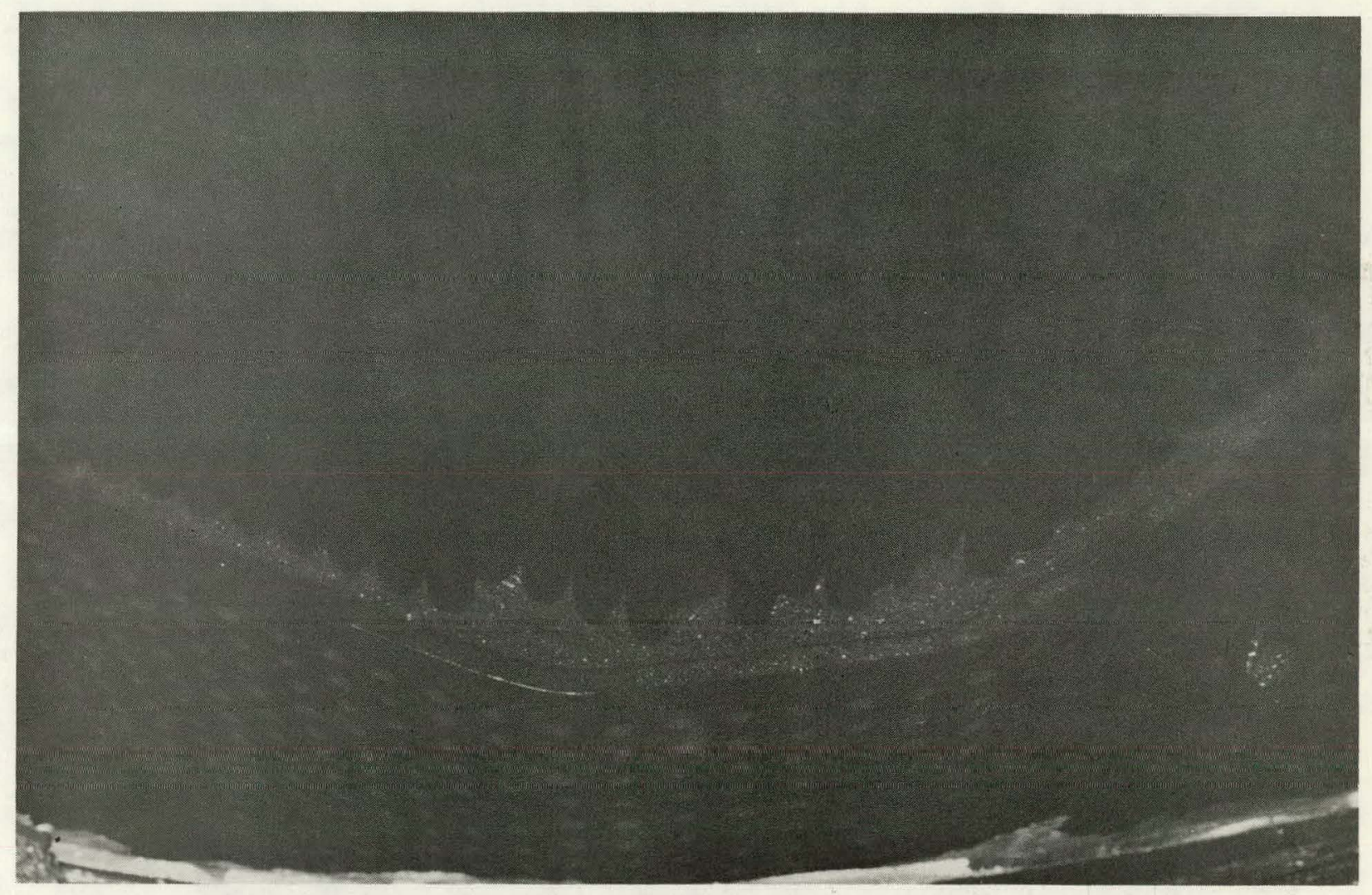

Fig. 7. View of superheater tube bundle looking down toward impingement baffle. This baffle faces the entry point of the hot duct. 


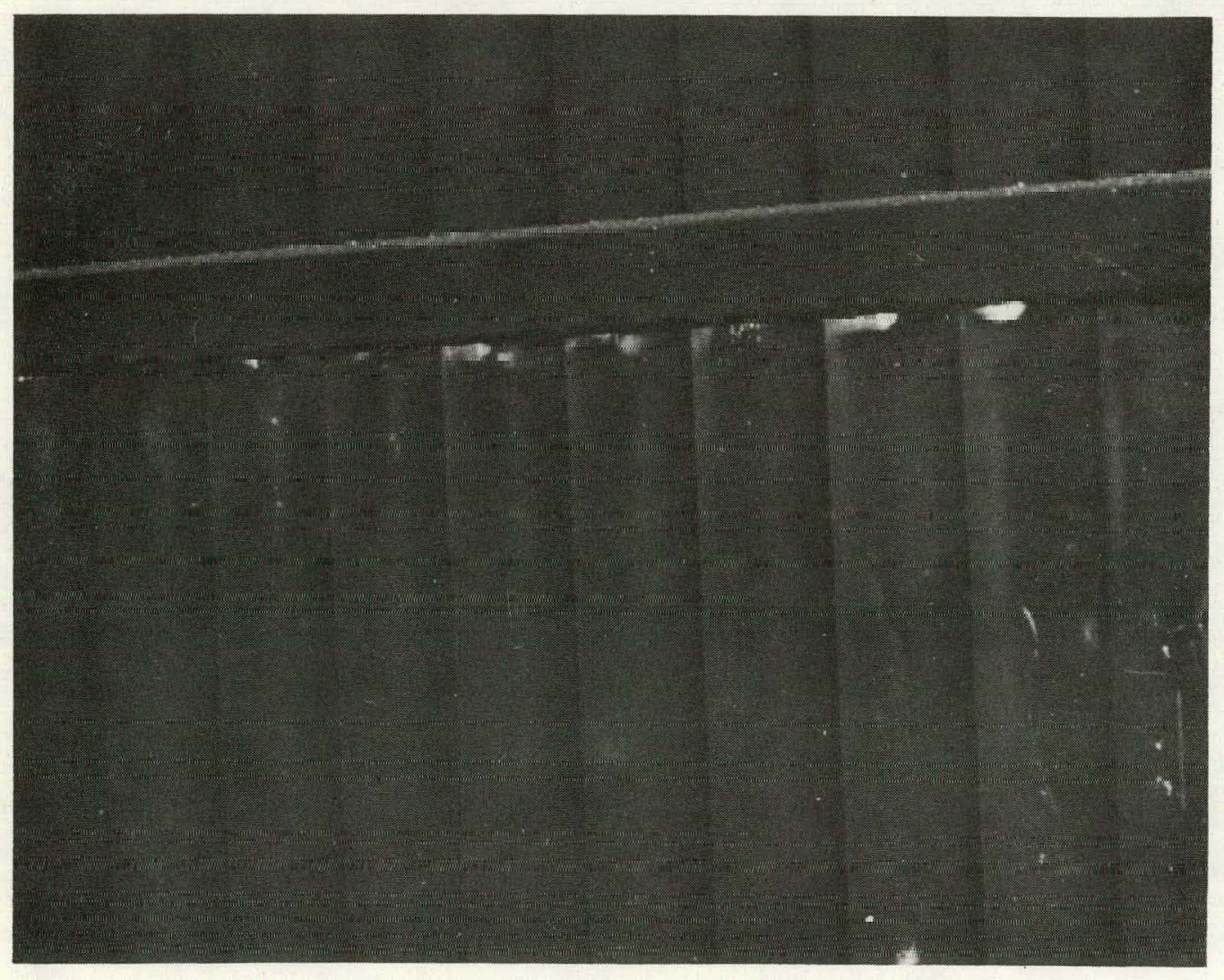

Fig. 8. Superheater bundle. Note wear areas where tubes pass through support plate. 


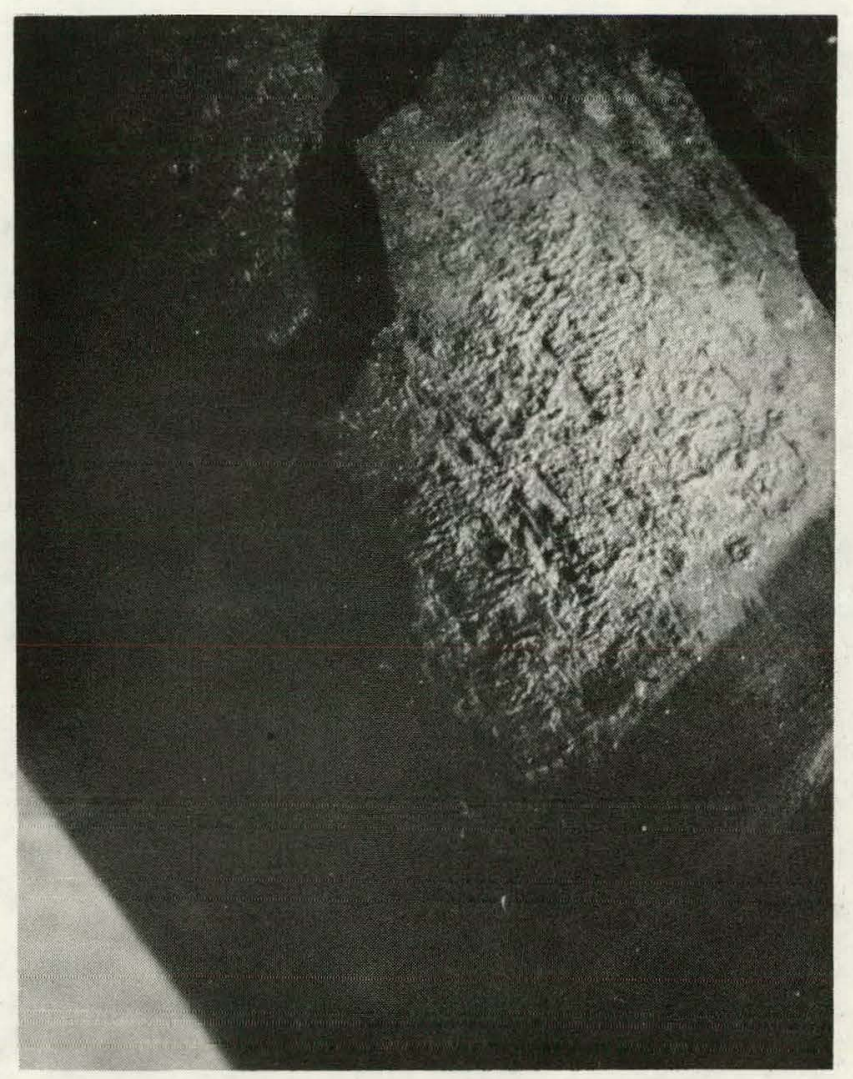

Fig. 9. Typical wear pattern on superheater inlet tube at support plate contact point 


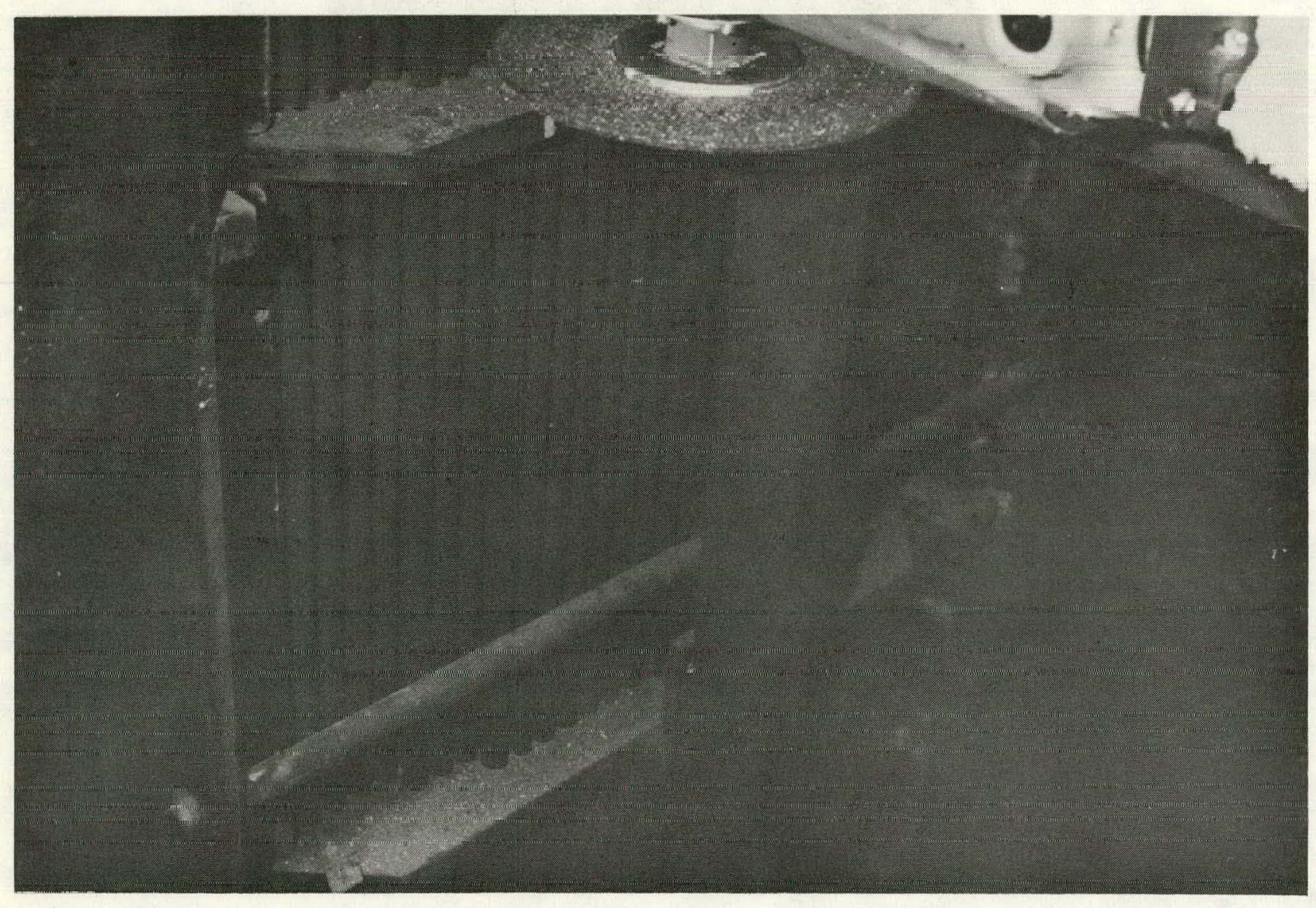

Fig. 10. Economizer tubes 


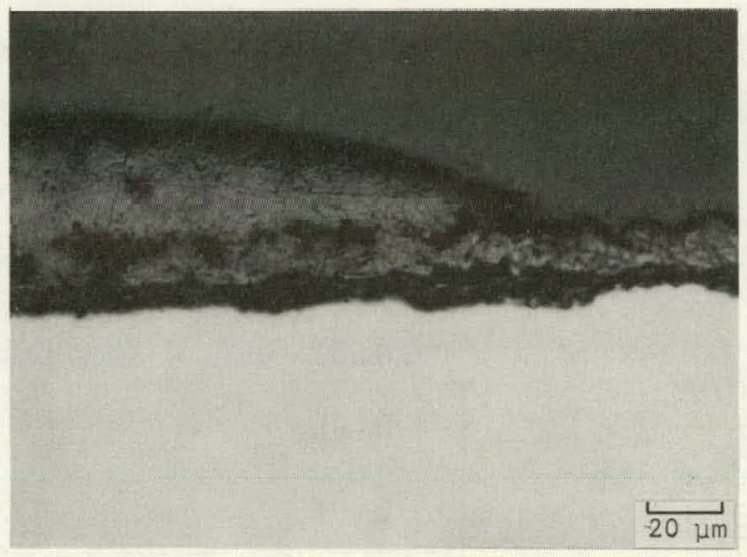

Unetched

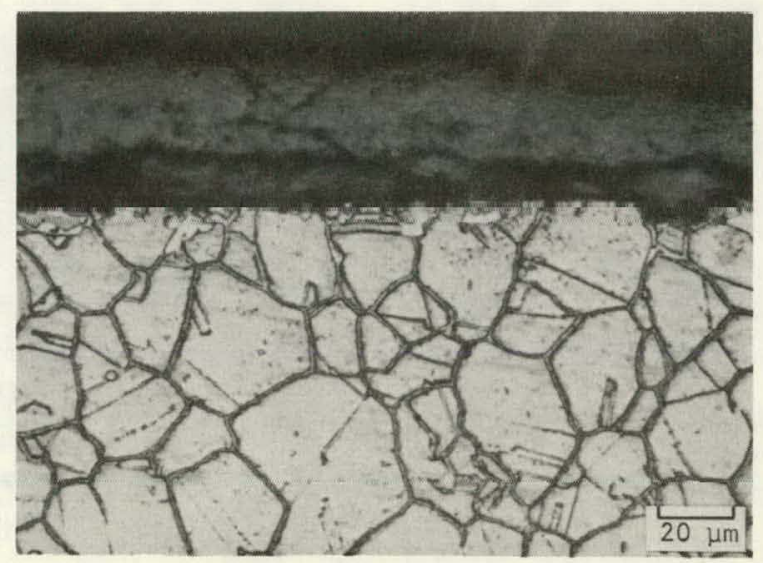

Electrolytic Oxalic Acid Etch

Helium Side

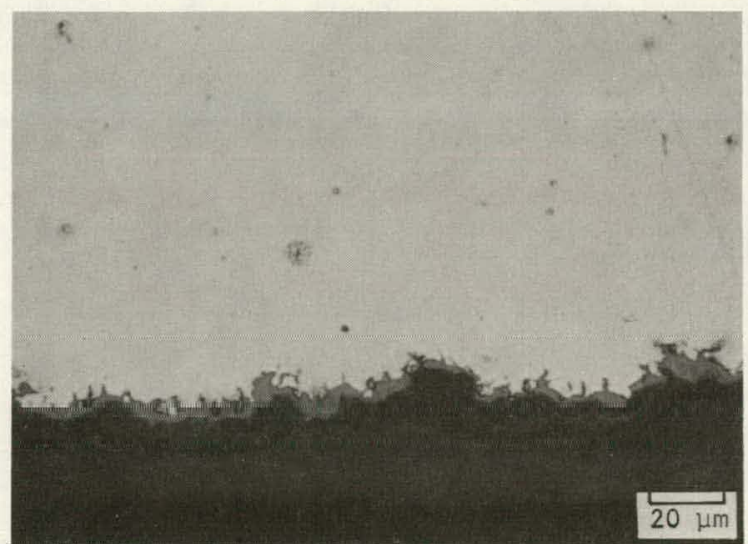

Unetched

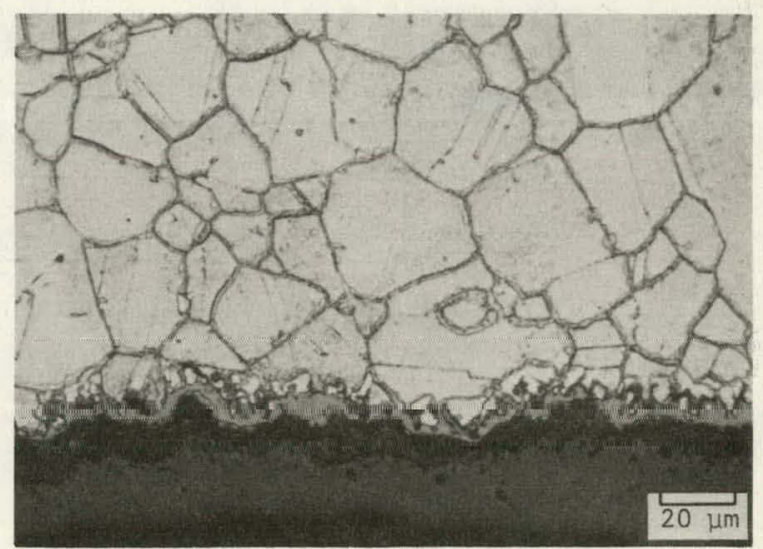

Electrolytic Oxalic Acid Etch

Steam Side

Fig. 11. Surface conditions on superheater outlet tube No. 20 (Alloy 800) 


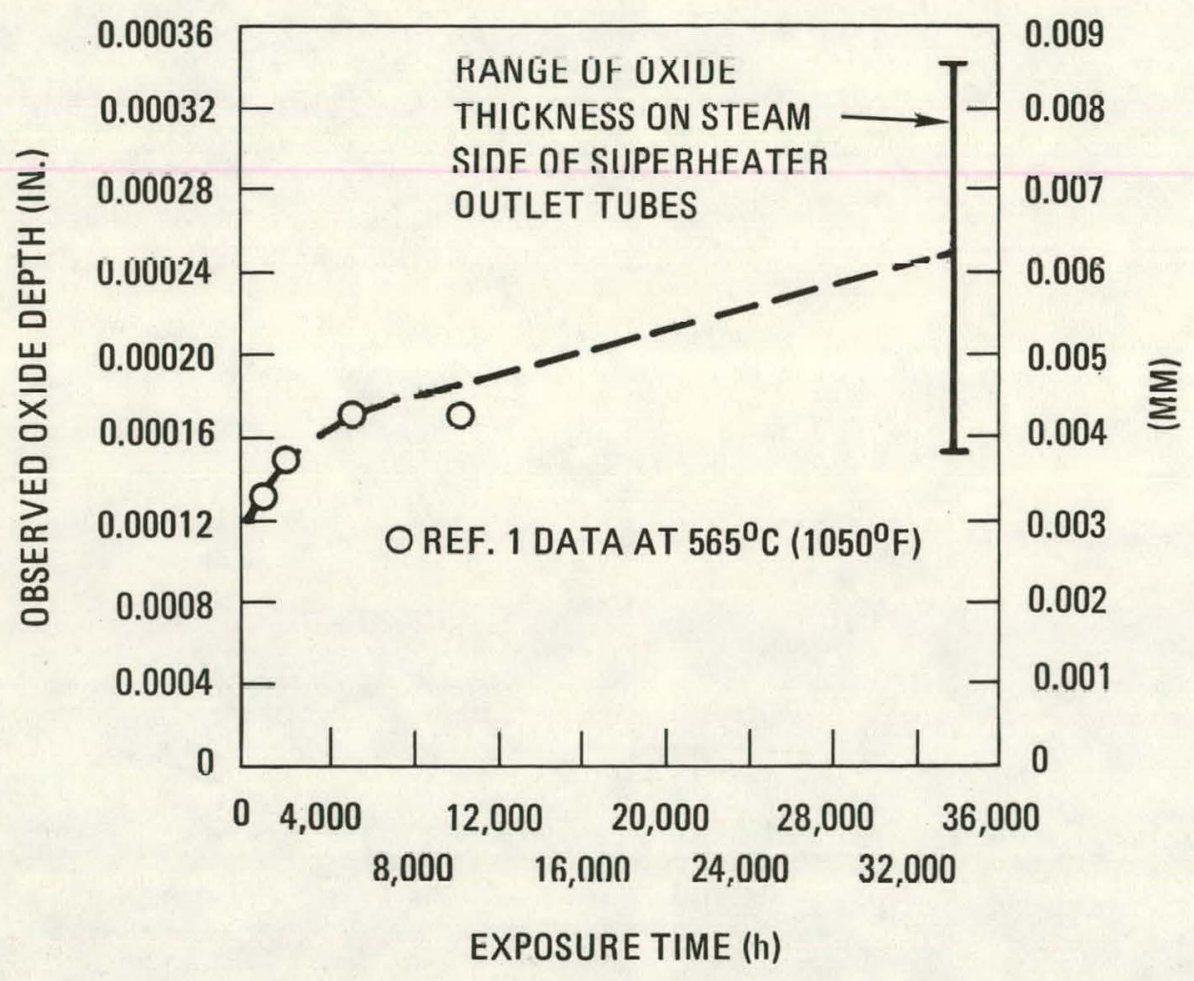

Fig. 12. Comparison of steam-side oxide film thickness on ouperheater outlet tubing with published data 

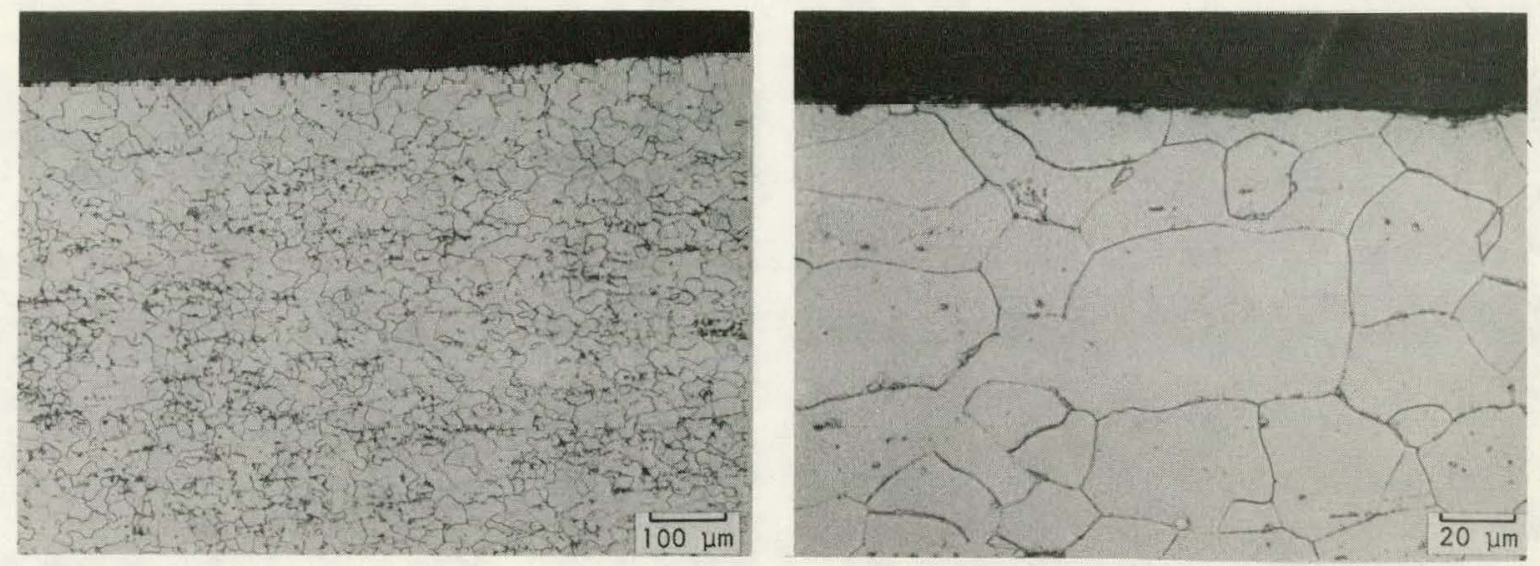

Helium Side
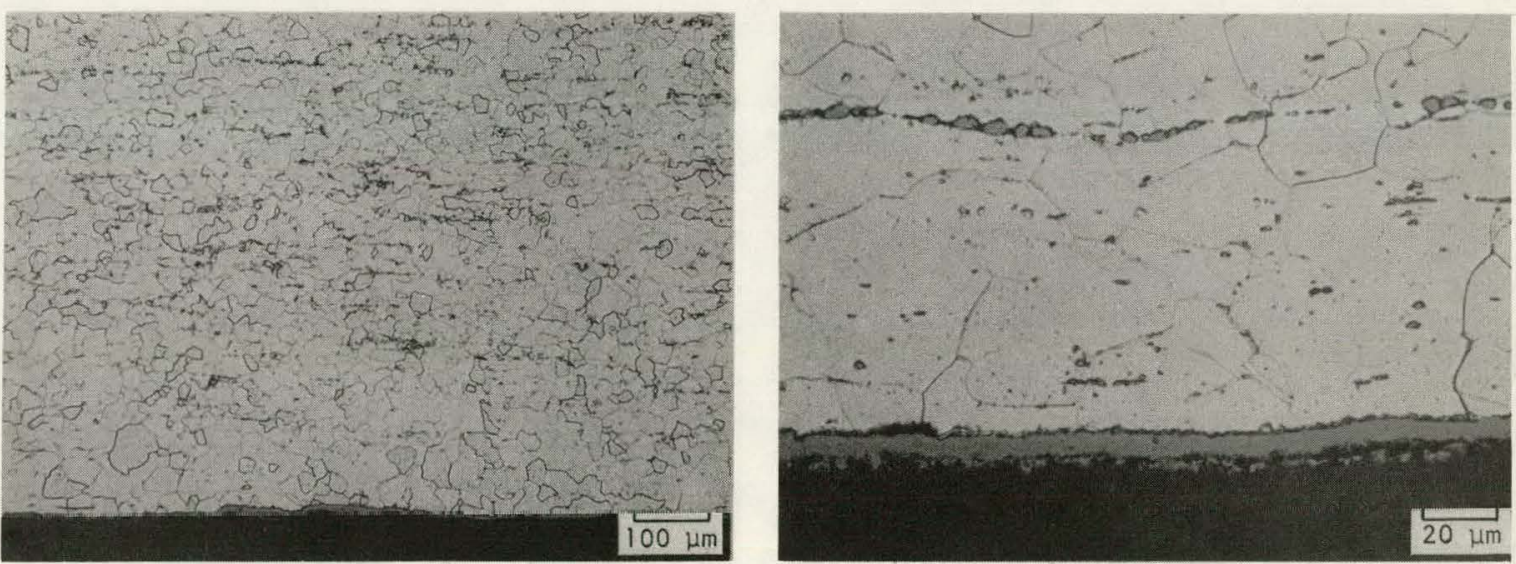

Water Side

Fig. 13. Surface features on typical economizer outlet tubing (ECO-68) (carbon steel) (Nital etch) 


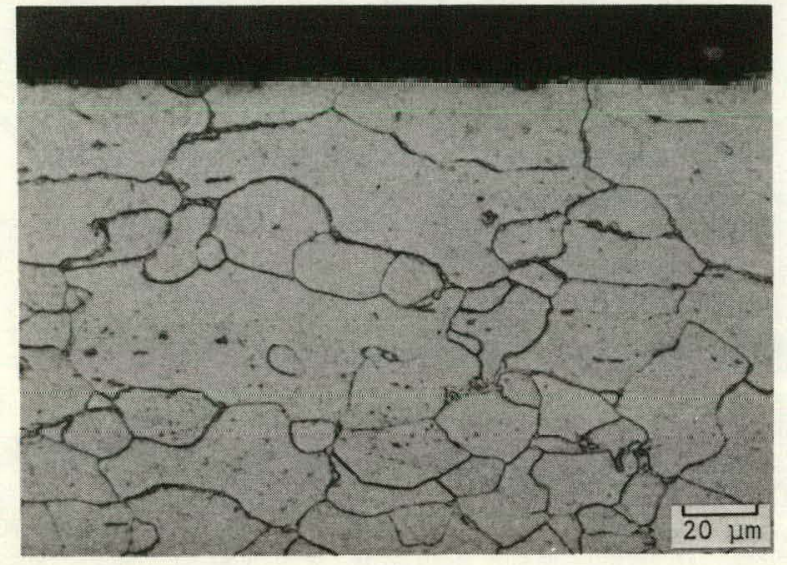

EVI-50

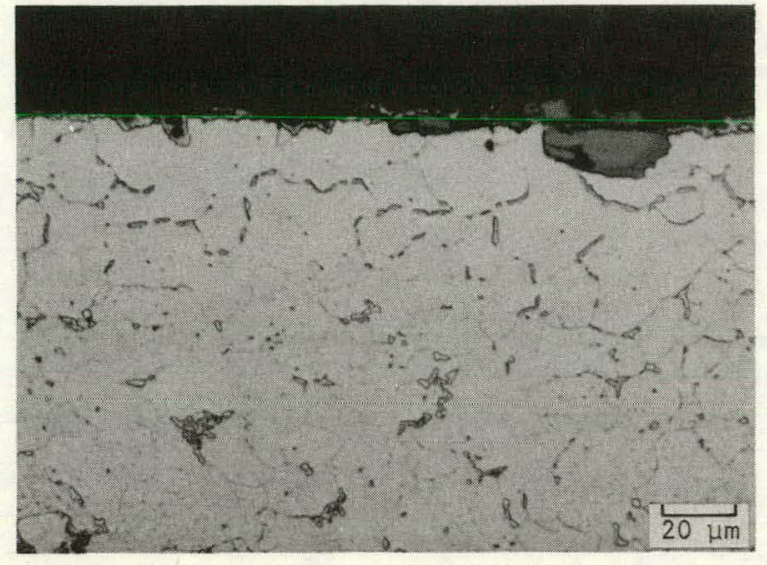

EVI-78

Helium Side

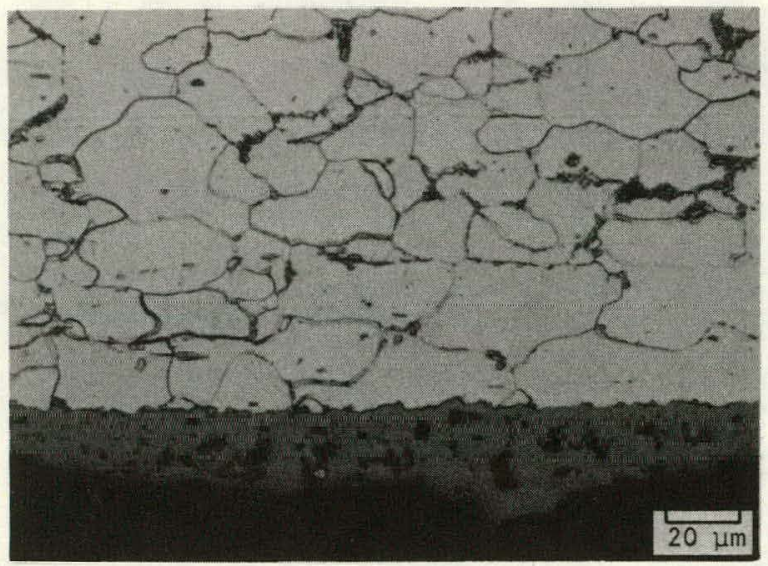

FVI -50

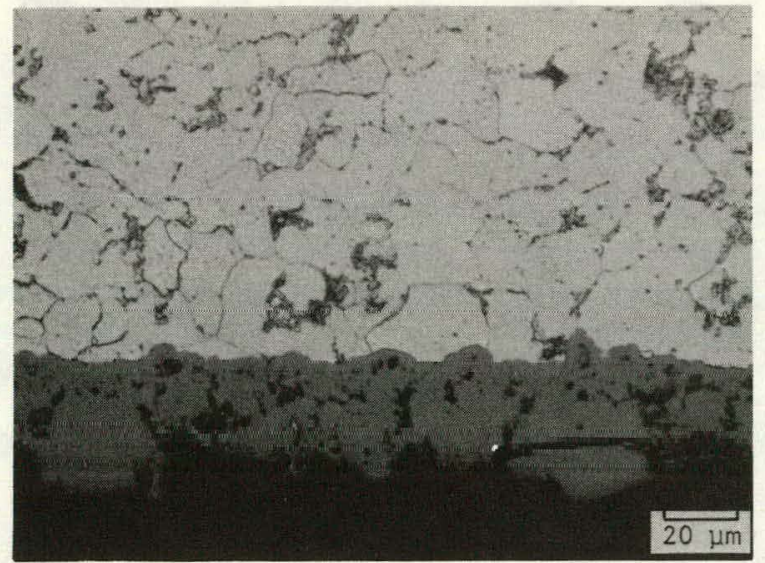

EVI-78

Steam Side

Fig. 14. Details of typical surface conditions of evaporator inlet tubing (carbon steel) (Nital etch) 


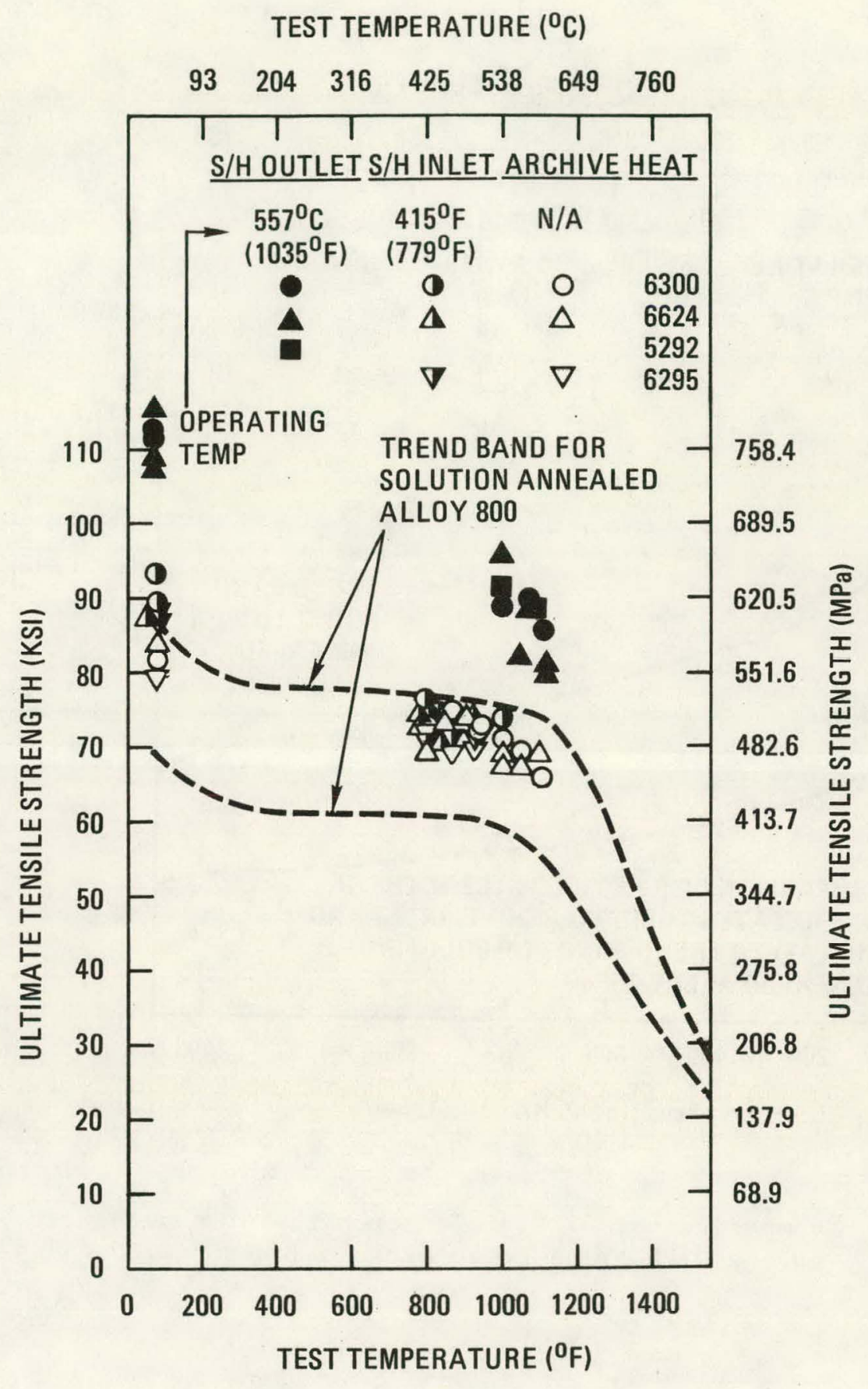

Fig. 15. Comparison of tensile strength data from superheater tubing with trend band for solution-annealed Alloy 800 


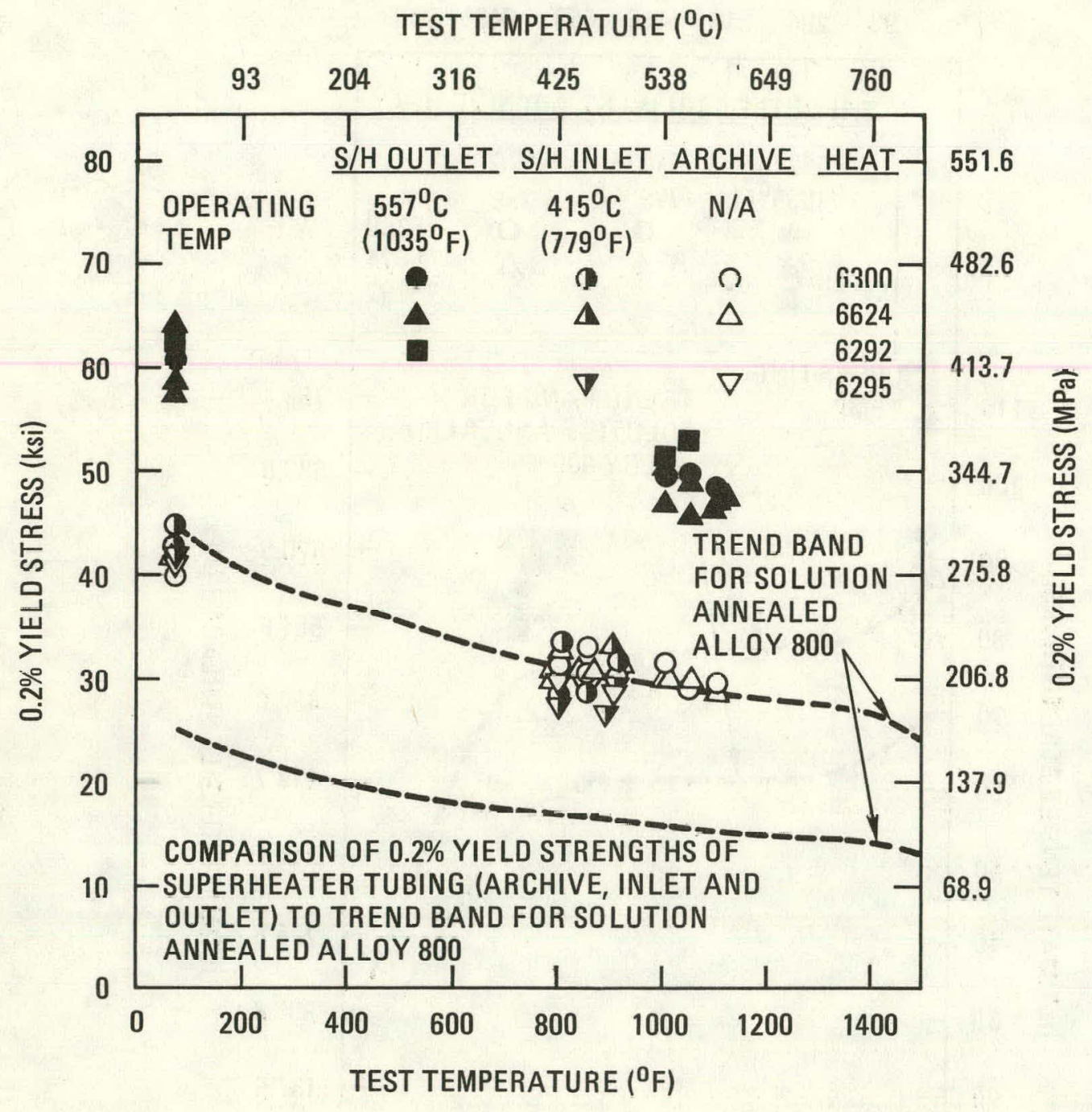

Fig. 16. Comparison of $0.2 \%$ yield strengths of superheater tubing with trend band for solution-annealed Alloy 800 


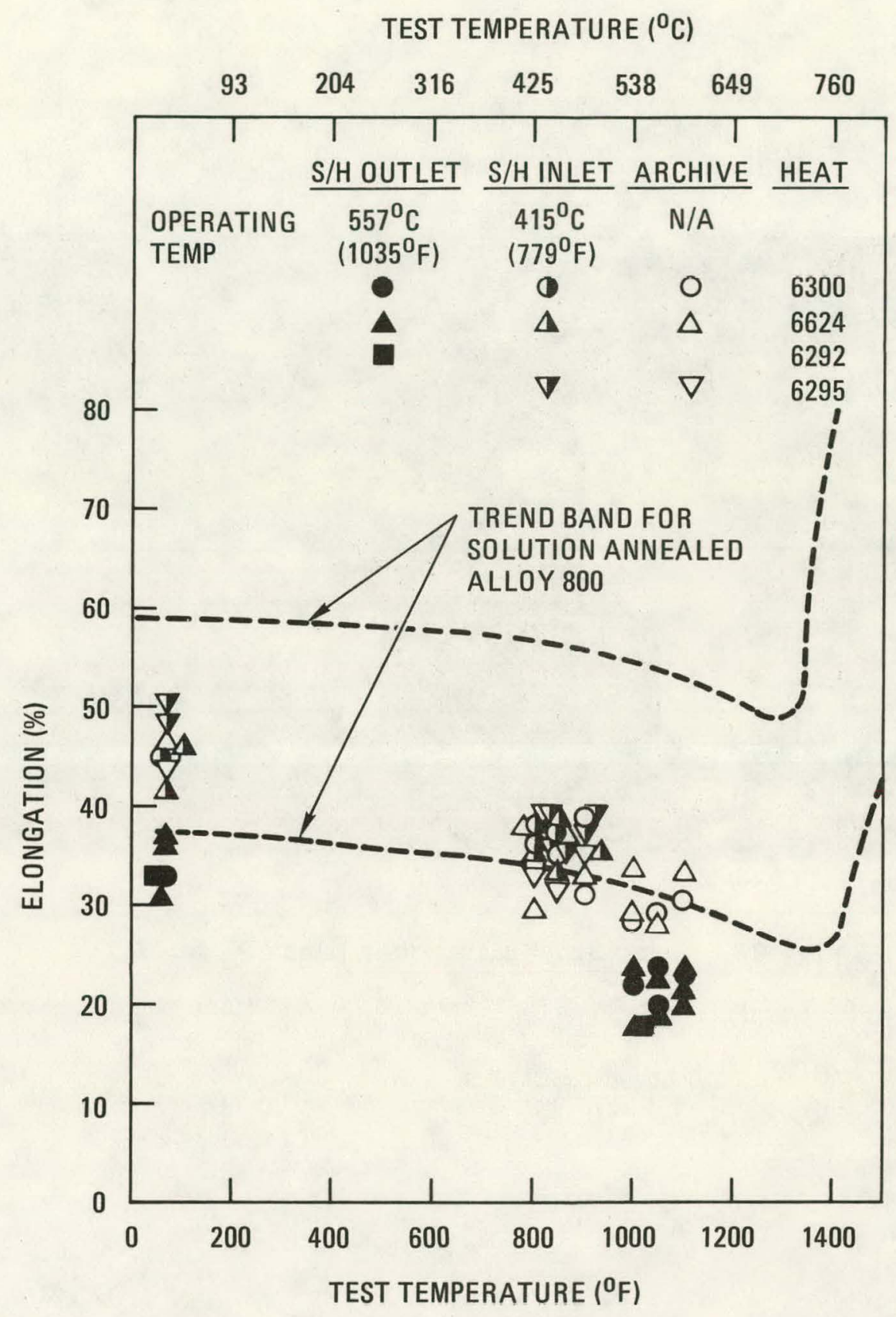

Fig. 17. Comparison of tensile elongation of superheater tubing with trend band for solution-annealed Alloy 800. Note: Superheater tube tests were performed on sub-size specimens with a $2.54-\mathrm{cm}$ (1-in.) gauge length. Solution-annealed Alloy 800 trend band is based on tests performed on standard-size tensile specimens with a $5.08-\mathrm{cm}$ (2-in.) gauge length. 


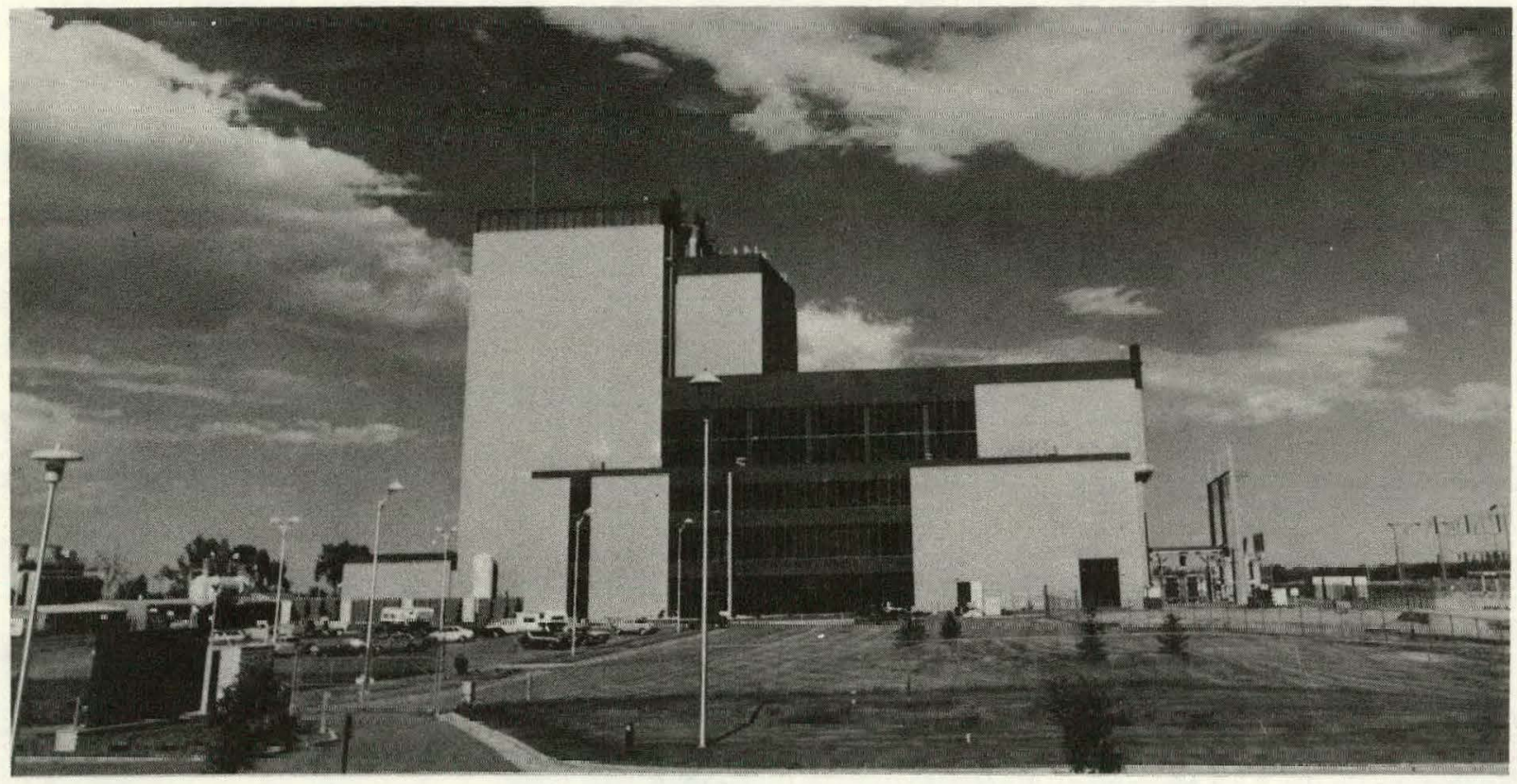

Fig. 18. Fort St. Vrain power plant 


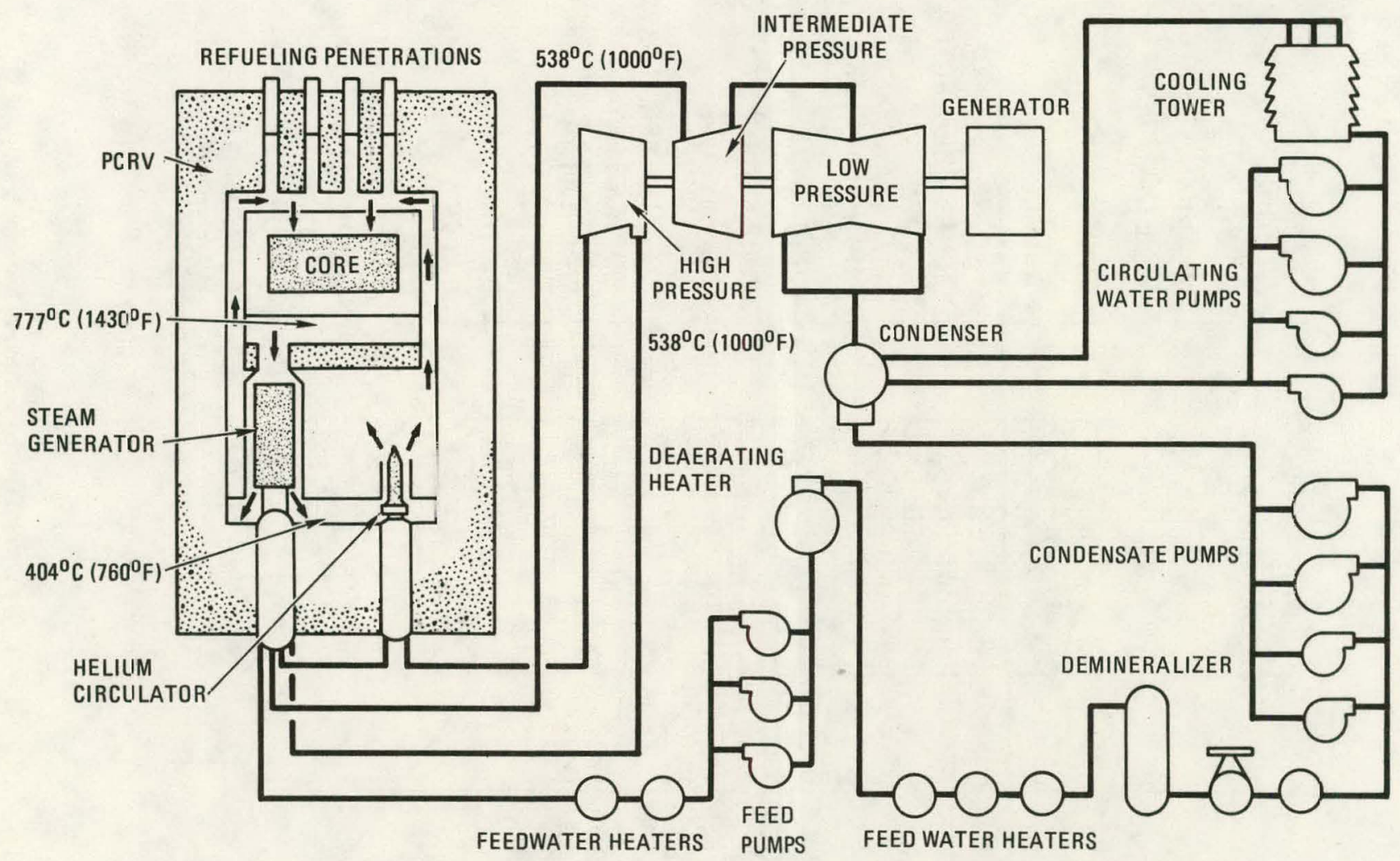

Fig. 19. Fort St. Vrain flow diagram 


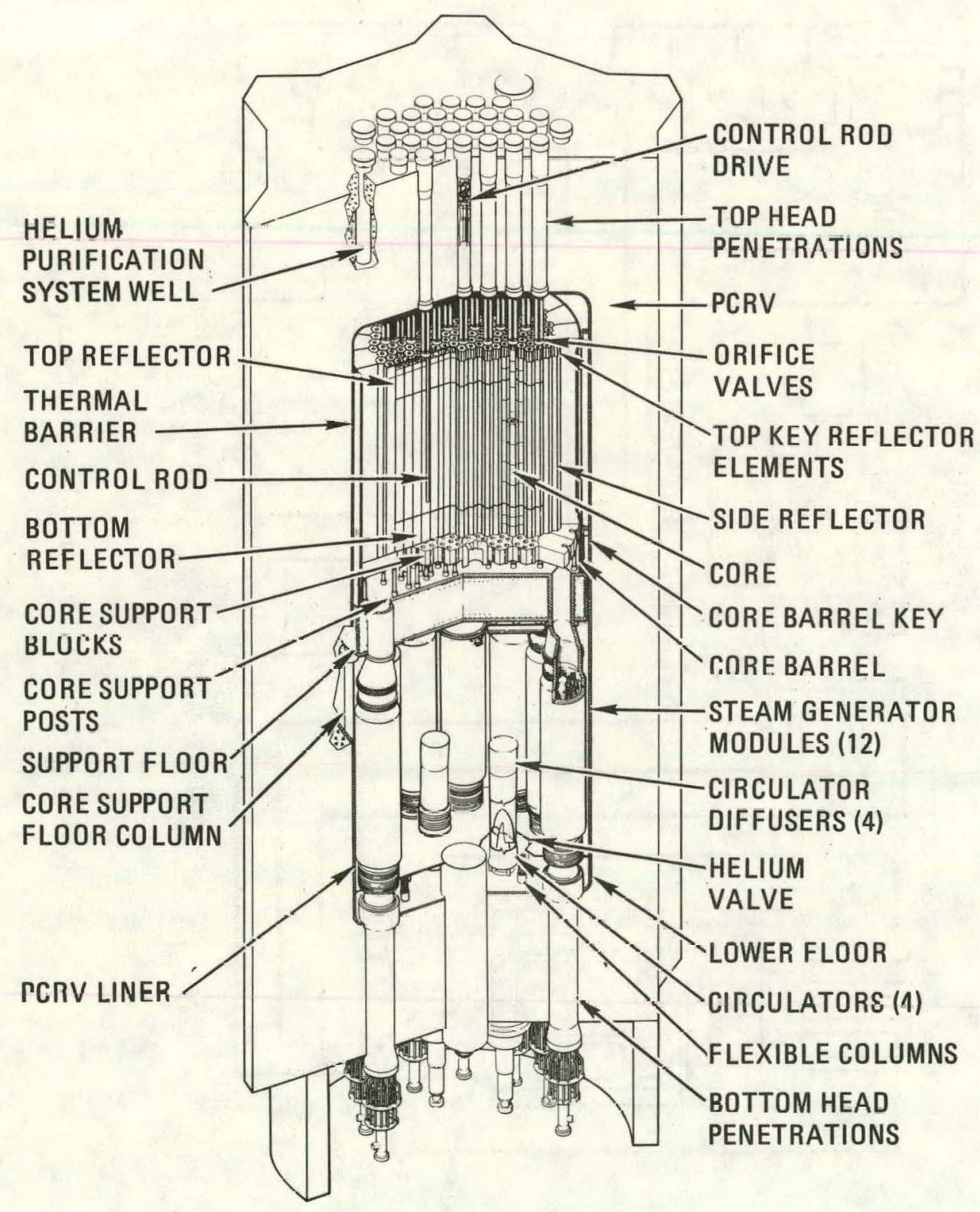

Fig. 20. Fort St. Vrain pressure vessel 


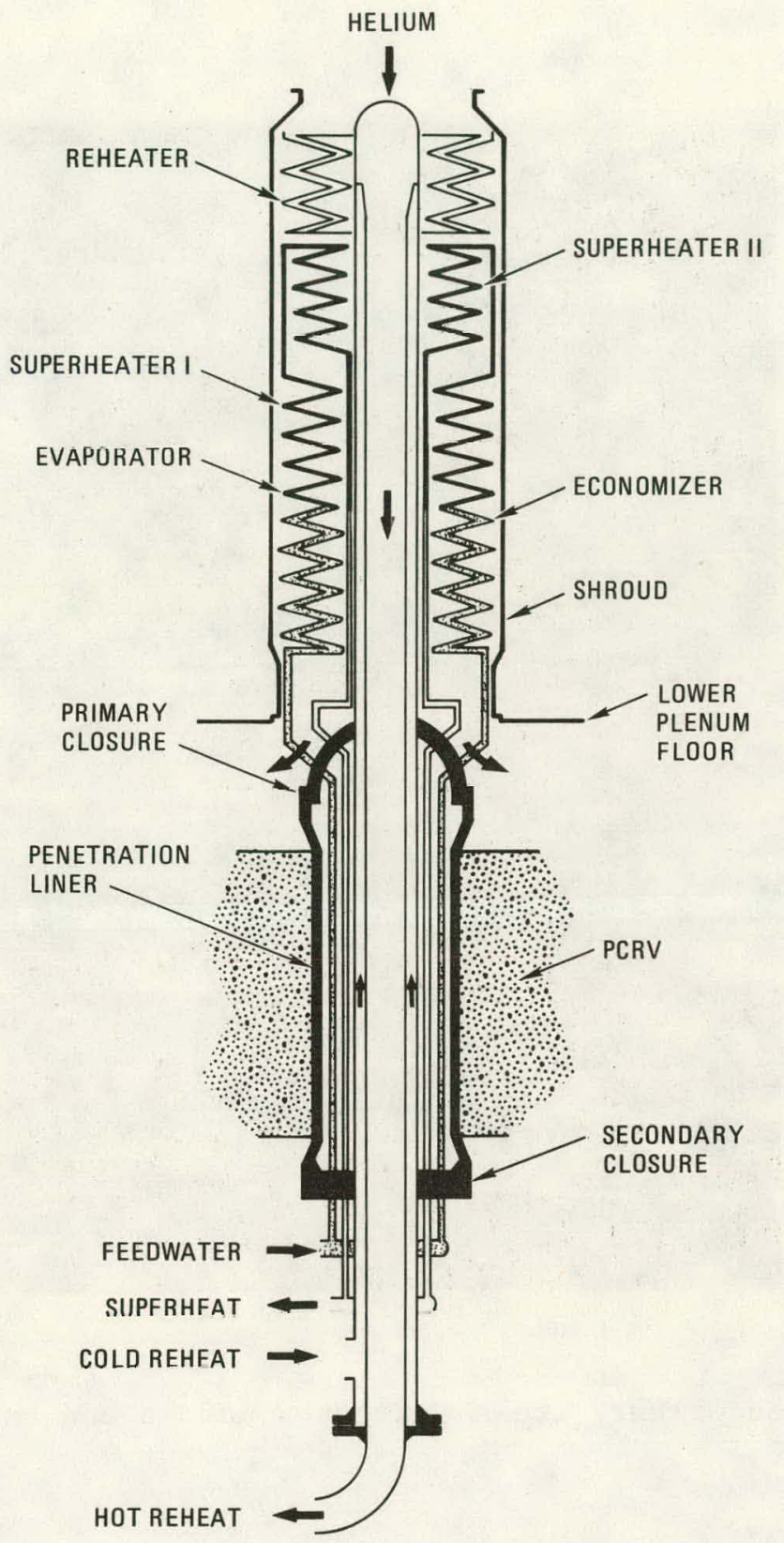

Fig. 21. Simplified schematic of Fort St. Vrain steam generator module 


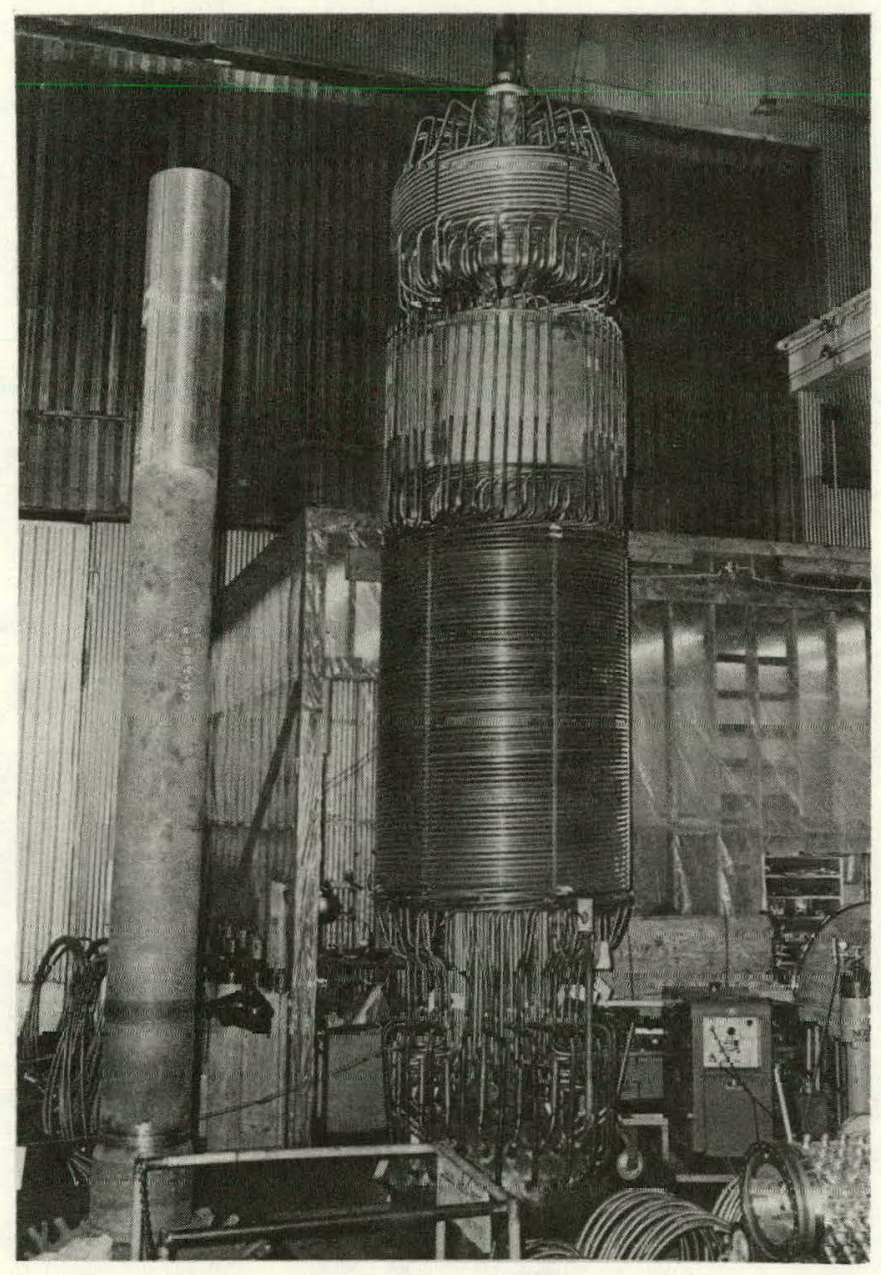

Tig. 22. Completed primary steam generator module and reheater standpipe 


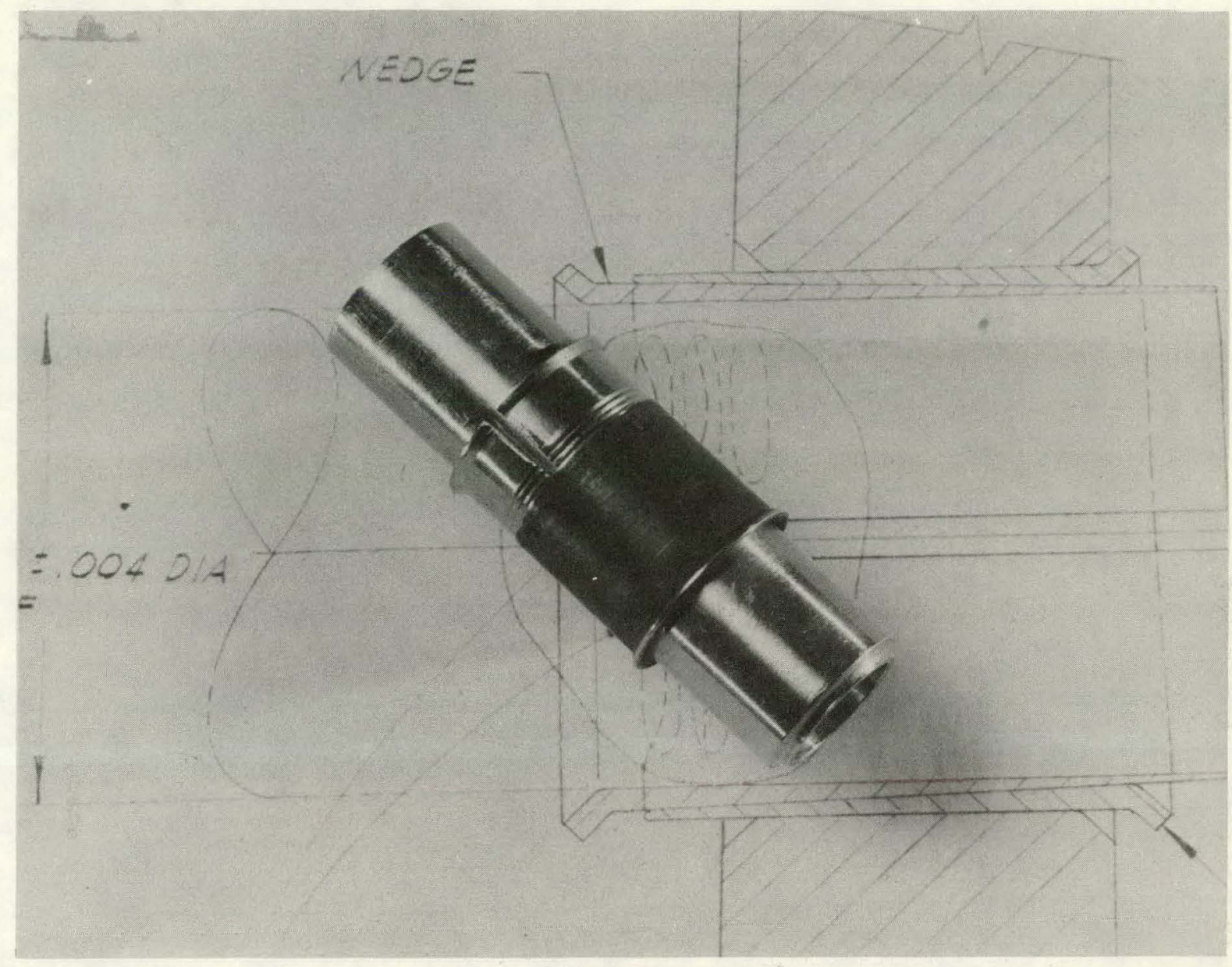

Fig. 23. Sleeve and wedge assembly 


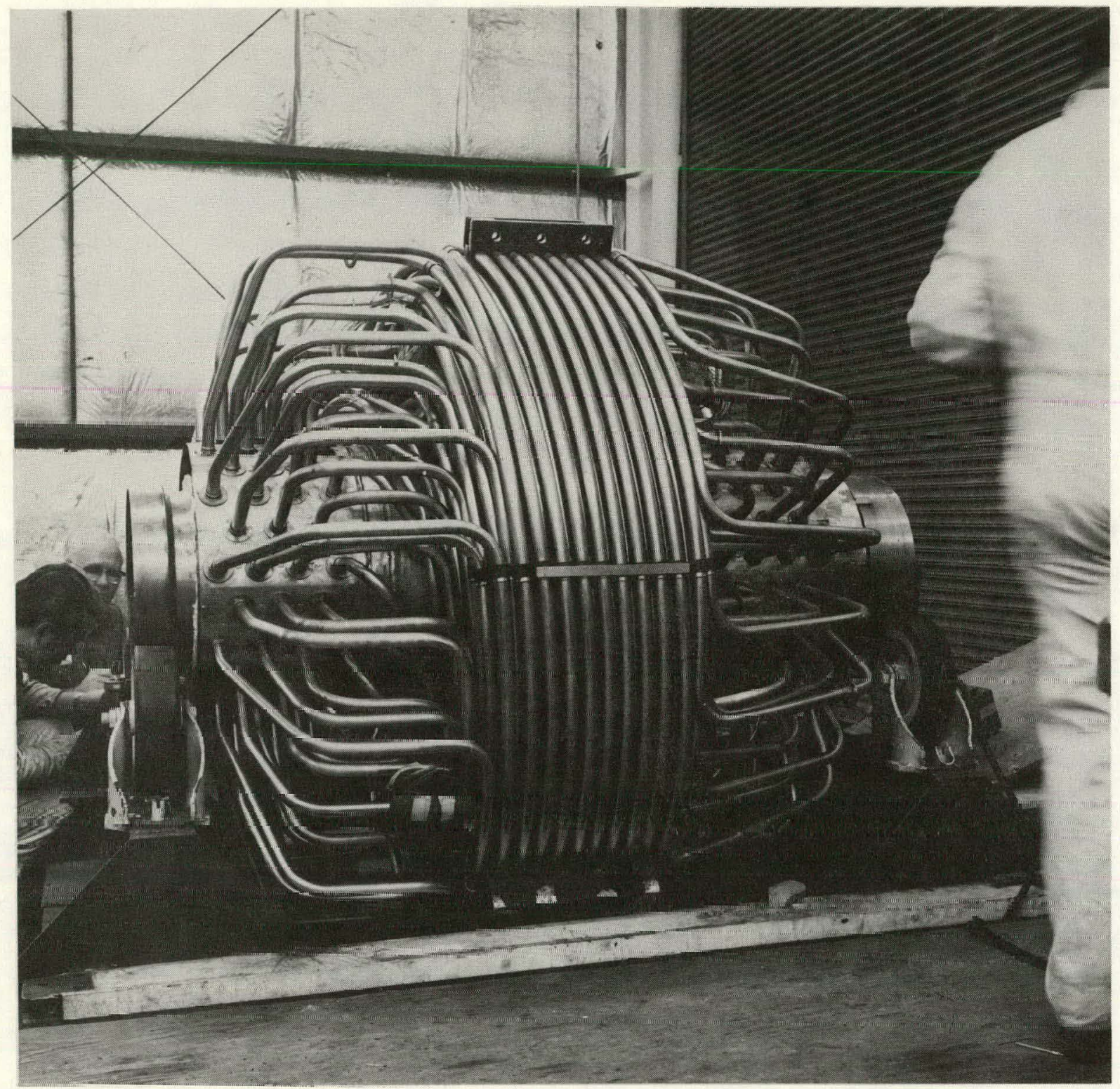

F1g. 24. Cumpleted reheater bundle. Note sleeves and wedges in place on tubing at support plate contact points. 
TABLE I

PRINCIPAL STEAM-GENERATING HTGRS

\begin{tabular}{|c|c|c|c|c|c|}
\hline NAME & $\left.\begin{array}{c}\text { SIZE } \\
{[M W(t)]}\end{array}\right]$ & SPONSOR/OWNER & LOCATION & TYPE & STATUS \\
\hline DRAGON & 20 & $\operatorname{OECD}(a)$ & WINFRITH, UK & EXPERIMENTAL UNIT & $\begin{array}{l}\text { OPERATED } 1966 \text { - } 1976 \\
\text { NOW DECOMMISSIONED }\end{array}$ \\
\hline$A \vee R^{\prime}(b)$ & 46 & $K F A^{(c)}$ & JULICH, FRG & EXPERIMENTAL UNIT & IN OPERATION SINCE 1967 \\
\hline PEACH BOTTOM & 115 & $\begin{array}{l}\text { AEC }{ }^{(d)}(D O E) / \\
\text { PHILADELPHIA } \\
\text { ELECTRIC }\end{array}$ & PENNSYLVAN!A, USA & SMALL PROTOTYPE & $\begin{array}{l}\text { OPERATED } 1967 \text { - } 1974 \\
\text { NOW DECOMMISSIONED }\end{array}$ \\
\hline FORT ST. VRAIN & 842 & $\begin{array}{l}\text { AEC }^{(\mathrm{d})} \text { (DOE)I } \\
\text { PUBLIC SERVICE CO. } \\
\text { OF COLORADI }\end{array}$ & COLORADO, USA & $\begin{array}{l}\text { DEMONSTRATION } \\
\text { REACTOR }\end{array}$ & IN DPERATION SINCE 12/76 \\
\hline THTR & 762. & VEW & SCHMEEHAUSEN, FRG & $\begin{array}{l}\text { DEMONSTRATION } \\
\text { REACTOR }\end{array}$ & SCHEDULED FOR STARTUP 1982 \\
\hline HTGR-SC $(f)$ & $\begin{array}{l}2000- \\
3000\end{array}$ & & & POWER REACTOR & IN DESIGN \\
\hline
\end{tabular}

(a) ORGANIZATION OF EUROPEAN COOPERATION AND DEVELOPMENT, EUROPEAN NUCLEAR ENERGY AGENCY.

(b) ARBEITSGEMEINSCHAFT VERSUCH REAKTOR.

(c) KERNFORSCHUNGSANLAGE.

(d) ATOMIC ENERGY COMMISSION.

(e) VEREINIGTE ELECKTRIZIATSWERKE WESTFALEN.

(f) HTGR-STEAM CYCLE. 
TABLE II

PRINCIPAL FEATURES OF HTGR STEAM GENERATORS \& HEAT EXCHANGERS

\begin{tabular}{|c|c|c|c|c|}
\hline \multirow[b]{2}{*}{ PLANT } & \multirow{2}{*}{$\begin{array}{c}\text { MAX } \\
\text { PFIMAR } \\
\text { CCOLANT } \\
\text { TEMP } \\
\left({ }^{\circ}{ }^{\circ} \text { C) }\left({ }^{0} \mathrm{~F} . I\right.\right. \\
\end{array}$} & \multicolumn{2}{|c|}{ STEAM/WATER CONDITIONS } & \multirow{2}{*}{$\begin{array}{l}\text { STEAM EENERATOR } \\
\text { CONFIGURATION AND TYPE }\end{array}$} \\
\hline & & $\begin{array}{l}\text { TEMPERATURE } \\
{\left[{ }^{0} \mathrm{C}\left({ }^{0} \mathrm{~F}\right)\right]}\end{array}$ & $\begin{array}{l}\text { PRESSURE } \\
\text { [(MPA) (psil)] }\end{array}$ & \\
\hline DRAGON & $830(152 E)$ & $203(397)$ & $1.6(232)$ & (NOT USECI FOR POWER GENERATION) \\
\hline$A \vee R^{(a)}$ & 950 (174i) & $505(941)$ & $7.5(1088)$ & INVOLUTE TUBE \\
\hline PEACH BOTTOM & $706(1292)$ & $536(997)$ & $10.2(1480)$ & U-TUBE FORCED-RECIRCULATION \\
\hline FORTST. VRAIN & $775(1427)$ & $\begin{array}{lr}\text { MIAIN STEAM } & 538(1000) \\
\text { REHEAT STEAM } & 538(1000)\end{array}$ & $\begin{array}{c}16.5(2400) \\
4.9(711)\end{array}$ & $\begin{array}{l}\text { ONCE-THROUG } \text { HELICAL BUNDLES } \\
\text { WITH REHEAT }\end{array}$ \\
\hline THTR & 750 (138?) & $\begin{array}{ll}\text { M.AIN STEAM } & 530(986) \\
\text { REHEAT STEAM } & 530(986)\end{array}$ & $\begin{array}{r}18.0(611) \\
5.6(812)\end{array}$ & $\begin{array}{l}\text { ONCE-THR JUGH HELICAL BUNDLES } \\
\text { WITH REHEAT }\end{array}$ \\
\hline HTGR-SC ${ }^{(b)}$ & 590 (1274) & $540(1004)$ & $16.5(2393)$ & ONCE-THROUGH HELICAL BUNDLES \\
\hline
\end{tabular}

(a) ARBEITSGEMEINSCHAFT VERSUCH REAKTQR.

(b) HTGR-STEAM CYCLE. 
TABLE III

PEACH BOTTOM OPERATING STATISTICS

\begin{tabular}{|c|c|}
\hline OPERATION PERIOD & JAN 1967 - OCT 1974 \\
\hline TOTAL POWER GENERATED & $1.38 \times 10^{6} M W(e) h$ \\
\hline AVEFAGE GROSS THERMAL EFFICIENCY & $37.2 \%$ \\
\hline $\begin{array}{l}\text { TOTAL TIME OF OPERATION WITH } \\
\text { COOLANT AT HIGH TEMPERATURE }\end{array}$ & $\sim 35,000 \mathrm{~h}$ \\
\hline STEAM GENERATOR LEAKAGE EXPERIENCE & $\begin{array}{l}\text { TWO SMALL LEAKS FROM THE SUPERHEATER } \\
\text { TUBESHEETS THAT WERE PRESENT AT } \\
\text { STARTUP PERSISTED AT THE SAME LEVEL } \\
\text { THROUGHOUT LIFE. }\end{array}$ \\
\hline
\end{tabular}


TABLE IV

PEACH BOTTOM ENVIRINNMENTS

\begin{tabular}{|c|c|}
\hline \multicolumn{2}{|l|}{ PRIMARY COOLANT } \\
\hline \multicolumn{2}{|c|}{ HELIUM AT $2.2 \mathrm{MPa}$ (319 psi) } \\
\hline IMPURITY & PARTIAL PRESSURE (Pa) \\
\hline $\mathrm{H}_{2}$ & 20 \\
\hline $\mathrm{H}_{2} \mathrm{O}$ & 1 \\
\hline $\mathrm{CO}$ & 1 \\
\hline $\mathrm{CO}_{2}$ & $<0.06$ \\
\hline $\mathrm{CH}_{4}$ & 2 \\
\hline \multicolumn{2}{|c|}{$\begin{array}{l}\text { SELUNDARY COOLANT. } \\
\text { FEEDWATER AT } 12 \mathrm{MPa} \text { (1741 psi) }\end{array}$} \\
\hline $\mathrm{pH}$ & 9.4 \\
\hline HYDRAZINE & $50-200 \mathrm{ppb}$ \\
\hline DISSOLVED $0_{2}$ & O (NONE DETECTED) \\
\hline \multicolumn{2}{|l|}{ STEAM DRUM CONDITIONS } \\
\hline $\mathrm{SiO}_{2} \mathrm{ION}$ & $100-500 \mathrm{ppb}$ \\
\hline CI ION & $100-600 \mathrm{ppb}$ \\
\hline $\mathrm{pH}$ & $8.8-9.2$ \\
\hline
\end{tabular}


TABLE V

PEACH BOTTOM STEAM GENERATOR MATERIALS AND OPERATING CONDITIONS

- HEAT TRANSFER TUBING

\begin{tabular}{|l|l|c|l|}
\hline & \multicolumn{1}{|c|}{ MATERIAL } & $\begin{array}{c}\text { MEAN WALL } \\
\text { TEMP }\left[{ }^{\circ} \mathrm{C}\left({ }^{\circ} \mathrm{F}\right)\right]\end{array}$ & \multicolumn{1}{|c|}{ ENVIRONMENTS } \\
\hline SUPERHEATER TUBING & $\begin{array}{l}\text { ALLOY 800 TO } \\
\text { B163-64 AND } \\
\text { CODE CASE 1325 }\end{array}$ & $\begin{array}{c}415-557 \\
(779-1035)\end{array}$ & HELIUM ON 0.D., STEAM ON I. D. \\
EVAPORATOR TUBING & C-Si STEEL TO & $329-343$ & HELIUM ON 0.D., STEAMNATER \\
& SA-192 & $(624-649)$ & ON I.D. \\
ECONOMIZER TUBING & C-STEEL TO & $232-315$ & HELIUM ON O.D., WATER ON I. D. \\
& SA-179 & $(450-559)$ & \\
\hline
\end{tabular}

- OTHER COMPONENTS

\begin{tabular}{|l|l|c|}
\hline & MATERIAL & TEMP $\left[{ }^{\circ} \mathrm{C}\left({ }^{\circ} \mathrm{F}\right)\right]$ \\
\hline SHROUDS & $\begin{array}{c}\text { 1 CR-1/2 MO TO } \\
\text { SA-387 Gr B }\end{array}$ & $\begin{array}{c}358 \\
(676)\end{array}$ \\
THERMAL INSULATION & 304 SS FOIL & $\begin{array}{c}400-700 \\
(752-1292)\end{array}$ \\
SUPERHEATER TUBESHEET & LOW ALLOY & $\begin{array}{c}540 \\
(1004)\end{array}$ \\
ETEEL.CLAD & WITH INC 82 & \\
ECONOMATOR AND & C-STEEL & $230-340$ \\
& & $(446-644)$ \\
\hline
\end{tabular}


TABLE VI

FORT ST. VRAIN STEAM GENERATOR MATERIALS AND' OPERATING CONDITIONS

\begin{tabular}{|c|c|c|c|}
\hline COMPONENTS & MATERIAL & $\begin{array}{c}\text { MAXIMUM } \\
\text { OPERATING } \\
\text { TEMP }\left[{ }^{0} \mathrm{C}\left({ }^{0} \mathrm{~F}\right)\right]\end{array}$ & ENVIRONMENTS \\
\hline SUPERHEATER II AND REHEATER & $\begin{array}{l}\text { ALLOY 800-SOLUTION } \\
\text { ANNEALED }\end{array}$ & $\begin{array}{l}730 \text { (1346) (TUBES) } \\
760 \text { (1400) (SUPPORTS) }\end{array}$ & HELIUM AND STEAM \\
\hline SUPERHEATER I AND EVAPORATOR & $21 / 4 \mathrm{Cr}-1 \mathrm{Mo}$ & $\begin{array}{l}540(1004) \text { (TUBES) } \\
620(1148) \text { (SUPPORTS) }\end{array}$ & $\begin{array}{l}\text { HELIUM AND } \\
\text { STEAMNATER }\end{array}$ \\
\hline ECONDMIZER & $1 / 2 \mathrm{Cr}-1 / 2 \mathrm{Mo}$. & $400(752)$ & HELIUM AND WATER \\
\hline $\begin{array}{l}\text { FEEDWATER LEADS AND } \\
\text { RINGHEADER }\end{array}$ & $1 / 2 \mathrm{Cr}-1 / 2 \mathrm{Mo} / \mathrm{B}-\mathrm{STEEL}$ & $260(500)$ & HELIUM AND WATER \\
\hline STEAM LEADS AND RINGHEADER & $\begin{array}{l}\text { ALLOY 800-MILL } \\
\text { ANNEALED }\end{array}$ & $540(1004)$ & HELIUM AND STEAM \\
\hline WEAR PROTECTION COATINGS & CHROMIUM CARBIDE & $750(1382)$ & HELIUM \\
\hline
\end{tabular}




\section{TABLE VII}

FORT ST. VRAIN OPERATING STATISTICS

INITIAL POWER OPERATION

TOTAL POWER GENERATED TO DATE

GROSS THERMAL EFFICIENCY (AT 70\% POWER)

EXPECTED GROSS THERMAL EFFICIENCY

AT $100 \%$ POWER

STEAM GENERATOR LEAKAGE EXPERIENCE
DECEMBER 1976

$>1.2 \times 10^{6} \mathrm{MW}(\mathrm{e}) \mathrm{h}$

$37 \%$

$39 \%$

ONE LEAK FROM A SUPERHEATER TUBE OCCURED IN NOVEMBER 1977 
TABLE VIII

\section{FORT ST. VRAIN ENVIRONMENTS}

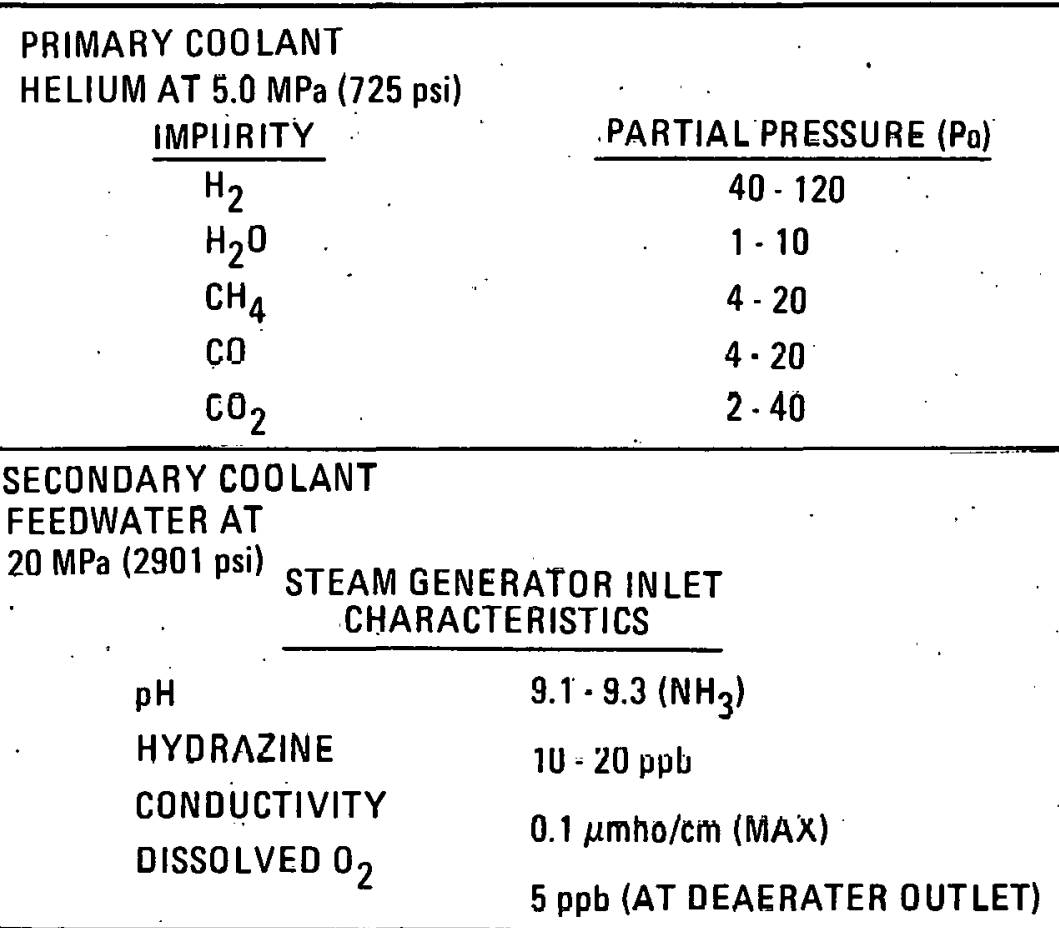




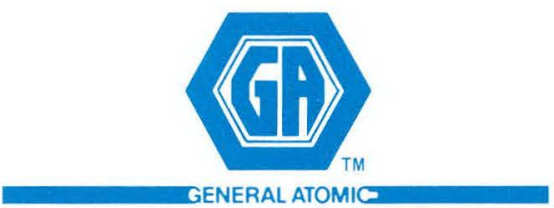

GENERAL ATOMIC COMPANY

P. O. BOX 81608

SAN DIEGO, CALIFORNIA 92138 